Journal of British Studies 59 (October 2020): 793-820. doi:10.1017/jbr.2020.127

(C) The North American Conference on British Studies, 2020. This is an Open Access article, distributed under the terms of the Creative Commons Attribution licence (http://creativecommons.org/licenses/by/4.0/), which permits unrestricted re-use, distribution, and reproduction in any medium, provided the original work is properly cited.

\title{
David Hume in Chicago: A Twentieth-Century Hoax
}

\section{Felix Waldmann}

\begin{abstract}
This article alleges that two letters attributed to the philosopher David Hume (1711-1776) were forged in the twentieth century. The letters were first published in 1972 and 1973 by Michael Morrisroe, an assistant professor of English in the University of Illinois, Chicago Circle, after which they became monuments of conventional scholarship on Hume's life and writings. Both letters are cited without qualification by scholars of Hume's thought in dozens of publications, including Ernest Campbell Mossner's celebrated Life of David Hume (1980), and John Robertson's entry for Hume in the Oxford Dictionary of National Biography (2004). This article reconstructs the history and transmission of Hume's extant letters and attempts to account for why the forgeries published by Morrisroe were accepted as genuine. It makes a systematic case against the authenticity of the letters, and focuses in particular on the question of whether Hume met the Jansenist homme de lettres Noël-Antoine Pluche (1688-1761) and had access to his library, in Reims, in 1734. The article concludes with a discussion of the implications of the exposé for modern editorial scholarship and intellectual history.
\end{abstract}

n January 1776, David Hume prepared his will and instructed his executor, Adam Smith, to "destroy" his "papers" post mortem, with the exception of the Dialogues Concerning Natural Religion and any other paper that did not date from the past "five years." In a codicil to the will, dated eighteen days before his death on 25 August 1776, Hume deprived Smith of this instruction and transferred it to his other executors: his brother, John Home of Ninewells and his printer, William Strahan. In this instance, Hume asked Home of Ninewells to "suppress" his "manuscripts," with the exception of the Dialogues and My Own Life, Hume's manuscript autobiography, which were to be "printed and published" by Strahan within two years of Hume's death. Hume's essays "Of Suicide" and "Of the Immortality of the Soul," prudentially suppressed in 1755-56, could be preserved and published optionally. ${ }^{2}$ No recension of Hume's will mentioned his "letters" or "correspondence"; it was not clear whether these were comprehended

Felix Waldmann is a Fellow of Christ's College, Cambridge. For invaluable help in the preparation of this article, he thanks Anne Abramson, Jeffrey Collins, James Harris, Lavinia Maddaluno, J. R. Milton, M. A. Stewart, Richard Virr, and Bill Zachs. The figures below appear by kind permission of the King's College Archive Centre, Cambridge and the Huntington Library, San Marino. Please direct any correspondence to few23@cam.ac.uk.

${ }^{1}$ For Hume's will (4 January and 15 April 1776), see CC8/8/125/858-68, National Records of Scotland (hereafter NRS), Edinburgh.

${ }^{2}$ For the codicil to Hume's will (7 August 1776), see MS 23159.24, National Library of Scotland (hereafter NLS), Edinburgh. For the suppression of Hume's essays, see Ernest Campbell Mossner, "Hume's Four Dissertations: An Essay in Biography and Bibliography," Modern Philology 48, no. 1 (1950): 37-57. 
by Hume's references to "papers" and "manuscripts," or exempted by Hume's stipulation to conserve whatever he had written within the past "five years." The polysemy of the word "suppress" - not strictly synonymous with "destroy" was additionally ambiguous. Were Hume's papers to be conserved by his executors but concealed from public view? Then there was the question of why Hume himself, knowing of his impending death, did not destroy the letters by his own hand. ${ }^{3}$

Strahan interpreted these ambiguities as a form of assent to the posthumous publication of Hume's correspondence, and he asked Smith and Home of Ninewells whether he could combine an edition of Hume's My Own Life with selections from Hume's letters. ${ }^{4}$ Smith was indignant. Hume's executors, he responded, were instructed to destroy his letters: "I know he always disliked the thought of his letters ever being published." ${ }^{\prime}$ Home of Ninewells, however, was more congenial. He retained his brother's manuscript correspondence and bequeathed it to his second son, David Hume the Younger (1757-1838), who would oversee the publication of his uncle's Dialogues Concerning Natural Religion in $1779 .{ }^{6}$ Hume the Younger would later lead an illustrious career as a judge and legal educator. He was appointed baron of the Exchequer in 1822, and he enjoyed the acquaintance of numerous literati in Scotland and abroad. ${ }^{7}$ He would also serve as a dutiful custodian and collector of his uncle's manuscripts, occasionally contacting Hume's correspondents and their legatees for any autograph relics by his kinsman that they happened to possess. ${ }^{8}$ In later life, Hume the Younger gifted a small number of these manuscripts to friends as keepsakes, ${ }^{9}$ and he sanctioned the publication of several others in literary periodicals. ${ }^{10}$ Upon his death in 1838 , he left the remainder of his collection to the Royal Society of Edinburgh. The collection remains the richest extant source of manuscript

\footnotetext{
${ }^{3}$ For Hume's terminal illness, see David Hume, The Letters of David Hume, ed. J. Y. T. Greig, 2 vols. (Oxford, 1932), 2:308, 315, 318-22, 324-26, 328, 332, 449-52; David Hume, New Letters of David Hume, ed. Raymond Klibansky and Ernest Campbell Mossner (Oxford, 1954), 211; David Hume, Further Letters of David Hume, ed. Felix Waldmann (Edinburgh, 2014), 92-96; John Home, A Sketch of the Character of Mr. Hume and Diary of a Journey from Morpeth to Bath, 23 April-1 May 1776, ed. David Fate Norton (Edinburgh, 1976), 13-28.

${ }^{4}$ Adam Smith, The Correspondence of Adam Smith, ed. Ernest Campbell Mossner and Ian Simpson Ross, 2nd ed. (Oxford, 1986), 222-23.

5 Smith, Correspondence, 223-24.

${ }^{6}$ For the descent of Hume's belongings, see David Fate Norton and Mary J. Norton, The David Hume Library (Edinburgh, 1996), 19-21. For Hume the Younger's edition of his uncle's Dialogues, see David Hume, The Natural History of Religion and Dialogues Concerning Natural Religion, ed. A. Wayne Colver and John Valdimir Price (Oxford, 1976), 112-28; Stephen W. Brown and Warren McDougall, introduction to The Edinburgh History of the Book in Scotland, vol. 2, Enlightenment and Expansion, 1707-1800, ed. Stephen W. Brown and Warren McDougall (Edinburgh, 2011), 22.

${ }^{7}$ For an authoritative biography of Hume the Younger, see G. Campbell H. Paton, ed., Baron David Hume's Lectures, 1786-1822, 6 vols. (Edinburgh, 1939-1958), 6:325-412.

${ }^{8}$ For Hume the Younger's attempts to harvest his uncle's letters, see NLS, MS 23158.10, MS 23158.27, MS 23764, fol. 22r-v; NLS, MS 23927, fol. 28r-v.

${ }^{9}$ For an example of such a gift, see Dk.6.27/6, Edinburgh University Library, inventoried in Hume, Further Letters of David Hume, 96.

${ }^{10}$ For example, a number of such letters were published in the Literary Gazette (London): 1 February 1817, 27; 29 November 1817, 341-42; 6 December 1817, 356; 13 December 1817, 375-76; 6 October 1821, 635-37; 13 October 1821, 648-49; 20 October 1821, 665-66; 10 November 1821, 711-12; 17 November 1821, 731-32; 24 November 1821, 745-46; 1 December 1821, 762; 25 October 1828, 683.
} 
material about Hume's life, containing practically every surviving letter that Hume received and dozens that he sent, in the form of drafts, retained copies, or returned originals. ${ }^{11}$

At the time of their donation, Hume's papers were regarded by the Society as a burden. Questions surrounded the Society's obligation to limit access to the correspondence, given the apparent implications of Hume's will and its codicil. When the literary journalist John Hill Burton (1809-1881) asked in 1843 to consult the papers for a biography of Hume, a committee was grudgingly convened to assess his intentions. ${ }^{12}$ Against this backdrop, a market for Hume's manuscripts was emerging among the cultists of the autograph letter. ${ }^{13}$ By 1900, 125 of Hume's autograph letters and manuscripts had been sold by Sotheby's alone. ${ }^{14}$ The next century witnessed a remarkable dispersion of Hume's autograph letters into the hands of dozens of collectors throughout the world; the most recent census counts at least 560 letters in at least sixty repositories, outside of the collection preserved by the Royal Society of Edinburgh, which is now on deposit in the National Library of Scotland. 15

In lockstep, the publication of Hume's correspondence burgeoned. Between 1766 and 1932, 515 of Hume's letters had appeared in print, extracted from the possession of Hume's addressees or their families and edited for public consumption. ${ }^{16}$ Burton's Life and Correspondence of David Hume (1846) and Letters of Eminent Persons to David Hume (1847) transcribed numerous letters from the Royal Society's holdings; George Birkbeck Norman Hill's Letters of David Hume to William Strahan (1888) produced a cache of unknown letters to William Strahan, Hume's friend and executor; J. Y. T. Greig's Letters of David Hume (1932) provided scholars with a critical edition of every known letter written by Hume; and Raymond Klibansky and Ernest Campbell Mossner's New Letters of David Hume (1954) offered a significant addendum to Greig's researches, partly in the service of Mossner's Life of David Hume (1954) - the definitive biography for much of the twentieth century. ${ }^{17}$

The discovery, sale, and publication of Hume's letters has continued without pause in the past six decades. Since 1954, 143 additional letters by Hume have appeared in dozens of publications, often singly. ${ }^{18}$ Numerous important literary manuscripts have also materialized. Between 2015 and 2018, four previously unknown manuscript letters by Hume were offered for sale in the United Kingdom and the United States. ${ }^{19}$ The most important of these letters, in which Hume responds to

${ }^{11}$ For the collection, see J. Y. T. Greig and Harold Beynon, Calendar of Hume MSS. in the Possession of the Royal Society of Edinburgh (Edinburgh, 1932); Ian C. Cunningham, "The Arrangement of the Royal Society of Edinburgh's David Hume Collection," The Bibliotheck 15, no. 1 (1988): 8-22.

${ }^{12}$ For Burton's work, see David Fate Norton, "Baron Hume's Bequest: The Hume Manuscripts and Their First Use," Year Book of the Royal Society of Edinburgh (1987): 26-43.

${ }^{13}$ For these "cultists," see A. N. L. Munby, The Cult of the Autograph Letter (London, 1962).

${ }^{14}$ For a list of these sales, see Hume, Further Letters of David Hume, 216-31.

${ }^{15}$ For a list of these repositories, see Hume, Further Letters of David Hume, 143-45.

${ }^{16}$ For a list of these publications, see Hume, Further Letters of David Hume, 196-206.

${ }^{17}$ For an overview of this scholarship, see Roland Hall, Fifty Years of Hume Scholarship: A Bibliographical Guide (Edinburgh, 1978), 1-14.

${ }^{18}$ For a list of these publications, see Hume, Further Letters of David Hume, 209-15.

19 Sotheby's, London, English Literature, Children's Books and Illustrations, catalogue, 15 December 2015, lot 2; Bonham's, New York, Fine Books and Manuscripts, catalogue, 9 March 2017, lot 152; 
Robert Traill (1720-1775), the Aberdeen clergyman and religious controversialist, was sold for the unusually high sum of $£ 40,000 .{ }^{20}$ The interest that this letter commands is understandable: Hume is responding to Traill's critique of his essay "Of Miracles" (1748). Yet this interest is amplified by the letter's distinction, among Hume's extant correspondence, as an item of intellectual substance. In prefacing his Letters of David Hume, J. Y. T. Greig anticipated the disappointment of his readers in noting that he had failed to discover any new letters of importance to the interpretation of Hume's philosophy, complementing the famous correspondence between Hume and Francis Hutcheson (1694-1746) on Hume's A Treatise of Human Nature or the remarkable exchange between Hume and Gilbert Elliot (1722-1777) on the Dialogues Concerning Natural Religion. ${ }^{21}$ Hume, it seemed, was reluctant to discuss philosophical matters in letters and diffident about the use of letters to chronicle his reading or significant ruminations.

The publication of two previously unknown but substantive letters in 1972-73 was thus a moment of tremendous importance for the scholarship of Hume's life and thought. In the Philological Quarterly and English Studies, the academic Michael Morrisroe recounted his discovery of the letters among the papers of a deceased collector and transcribed each letter with a learned introduction and apparatus. ${ }^{22}$ The letters have since entered the standard narrative of Hume's biography and writings, as monuments of Hume's correspondence at two crucial moments in his life: visiting Reims as a young man in 1734, and residing in Paris as a diplomat in 1765. Both letters offer a considerable addition to our knowledge of Hume's intellectual development. The letter of 1734 reveals Hume's interest in the work of George Berkeley (1685-1753) and his acquaintance with Noël-Antoine Pluche (1688-1761), the author of Le spectacle de la nature (1732-1750). The letter of 1765 shows Hume's persistent interest in writing an "ecclesiastical history" and his first steps in procuring the scholarly materials necessary for its composition. The first letter, excerpted at length in the second edition of Mossner's Life of David Hume (1980), is routinely cited by scholars as evidence of Hume's familiarity with Pluche and his early awareness of Berkeley's Treatise Concerning the Principles of Human Knowledge (1710). ${ }^{23}$ The second letter, although less frequently cited,

Sotheby's, London, English Literature, History, Science, Children's Books and Illustrations, catalogue, 9-10 July 2018, lot 307.

${ }^{20}$ For a transcription of the letter (NLS, Acc. 13962), see Felix Waldmann, "Additions to Further Letters of David Hume," Hume Studies, forthcoming.

${ }^{21}$ Hume, The Letters of David Hume, 1:xxii, 32-35, 36-40, 45-48, 150-58.

${ }^{22}$ Michael Morrisroe, Jr., "Hume's Ecclesiastical History: A New Letter," English Studies 53, no. 5 (1972): 431-33; Michael Morrisroe, Jr., "Did Hume Read Berkeley? A Conclusive Answer," Philological Quarterly 52, no. 2 (1973): 310-15.

${ }^{23}$ For direct citations of the letter, see Richard B. Schwartz, "Berkeley, Newtonian Space, and the Question of Evidence," in Probability, Time, and Space in Eighteenth-Century Literature, ed. Paula R. Backscheider (New York, 1979), 259-73, at 273n26; Ernest Campbell Mossner, The Life of David Hume, 2nd ed. (Oxford, 1980), 97nl, 626; Eugenio Lecaldano, "La filosofia e gli epistolari: Il ruolo delle 'lettere' nella storiografia filosofica su Hume," Rivista di Storia della Filosofia 40, no. 4 (1985): 655-90, at 674 n47; Colin M. Turbayne, "Hume's Influence on Berkeley," Revue Internationale de Philosophie 154, no. 3 (1985): 259-69, at 263n7; John W. Davis, "Bayle, Berkeley and Hume's Metaphysics," in Philosophie et culture: Actes du XVIIe congrès mondial de philosophie, ed. Venant Cauchy (Montreal, 1988), 358-64, at 360; M. A. Box, "How Much of Berkeley Did Hume Read?," Notes and Queries 36, no. 1 
features in scholarship on Hume's historical writing and authorial self-fashioning. ${ }^{24}$ It is the contention of what follows that both of the letters are forgeries - and that their author was not Hume at all but the perpetrator of a twentieth-century hoax. This suggestion is not new. Published doubts have surrounded the two letters since 1984, as we will see. But the doubts have been expressed too quietly or qualifiedly. The hoax is now so thoroughly embedded in the historiography of Hume's life and writings that scholars no longer realize that they are trafficking in its fabrications.

\section{THE TRANSMISSION OF HUME'S MANUSCRIPTS}

In order to substantiate the allegation at the heart of this article, it is important to gain a clearer sense of the range and character of Hume's surviving letters and the conventions that are typically applied to the assessment of their authenticity. There

(1989): 65-66; M. A. Box, The Suasive Art of David Hume (Princeton, 1990), 72n27; Mouza Raskolnikoff, Histoire romaine et critique historique dans l'Europe des Lumières: La naissance de l'hypercritique dans l'historiographie de la Rome antique (Rome, 1992), 146; Domenico Bosco, 'La 'leggerezza' del piacevole: La 'Théorie des Sentiments Agréables' di Lévesque de Pouilly”, Rivista di Filosofia Neo-Scolastica 90, no. 4 (1998): 3-54, at 10n28; C. J. McCracken and I. C. Tipton, eds., Berkeley's Principles and Dialogues: Background Source Materials (Cambridge, 2000), 209, 221n4; Roderick Graham, The Great Infidel: A Life of David Hume (East Linton, 2004), 54; Tom Jones, Pope and Berkeley: The Language of Poetry and Philosophy (Basingstoke, 2005), 184n12; Kenneth P. Winkler, bibliography of The Cambridge Companion to Berkeley, ed. Kenneth P. Winkler (Cambridge, 2005), 407-34, at 434; Ching-Shui Li, La régularité, l'ordre et le sensualisme chez David Hume (Paris, 2007), 118; Talia Mae Bettcher, Berkeley's Philosophy of Spirit: Consciousness, Ontology and the Elusive Subject (London, 2007), 154nl3; Ian Simpson Ross, "The Emergence of David Hume as a Political Economist: A Biographical Sketch," in David Hume's Political Economy, ed. Margaret Schabas and Carl Wennerlind (New York, 2008), 31-48, at 40; Kenneth R. Merrill, Historical Dictionary of Hume's Philosophy (Plymouth, 2008), 342; Roger L. Emerson, Essays on David Hume, Medical Men and the Scottish Enlightenment (Abingdon, 2009), 85n30; Damian Ilodigwe, Berkeley: A Portrait (Newcastle upon Tyne, 2010), 38; Emilio Mazza, "David's 'Fool': Scepticism and Certainty in the Conclusion of the First Book," in Hume Readings, ed. Lorenzo Greco and Alessio Vaccari (Rome, 2012), 121-62, at 16ln175; Stefanie Rocknak, Imagined Causes: Hume's Conception of Objects (Dordrecht, 2013), 275; Jason Fisette, "Hume on the Lockean Metaphysics of Secondary Qualities," Hume Studies 40, no. 1 (2014): 95-136, at 127n31. For works that do not cite the letter but restate its implications (Hume's meeting with Pluche, reading of Berkeley in Reims), see Gerhard Streminger, David Hume: Der Philosoph und sein Zeitalter (Stuttgart, 1995), 120; John Robertson, "Hume, David (1711-1776)," in Oxford Dictionary of National Biography, ed. H. C. G. Matthew and Brian Harrison, 60 vols. (Oxford, 2004), 28:740-58, at 742; Margaret Schabas, The Natural Origins of Economics (Chicago, 2006), 68; Mikko Tolonen, "Politeness, Paris and the Treatise," Hume Studies 34, no. 1 (2008): 21-42, at 34n2; Stephen Gaukroger, The Collapse of Mechanism and the Rise of Sensibility: Science and the Shaping of Modernity, 1680-1760 (Oxford, 2010), 439; Alexander Broadie, Agreeable Connexions: Scottish Enlightenment Links with France (Edinburgh, 2012), 28-29; Annemarie Butler, "Hume's Early Biography and $A$ Treatise of Human Nature," in Cambridge Companion to Hume's Treatise, ed. Donald C. Ainslie and Annemarie Butler (Cambridge, 2015), 1-13, at 4; Tamás Demeter, David Hume and the Culture of Scottish Newtonianism: Methodology and Ideology in Enlightenment Inquiry (Boston, 2016), 152; Eric Palmer, "Less Radical Enlightenment: A Christian Wing of the French Enlightenment," in Reassessing the Radical Enlightenment, ed. Steffen Ducheyne (London, 2017), 197-222, at 201.

${ }^{24}$ For direct citations of the letter, see Mossner, Life of David Hume, 648; Lothar Kreimendahl, "Über die Verflechtung von Stil und Ziel in Oeuvre David Humes," Zeitschrift für Philosophische Forschung 43, no. 1 (1989): 5-31, at 29n116; Moritz Baumstark, "The End of Empire and the Death of Religion: A Reconsideration of Hume's Later Political Thought," in Philosophy and Religion in Enlightenment Britain: New Case Studies, ed. Ruth Savage (Oxford, 2012), 231-57, at 252n83. 
are approximately between 800 and 1,000 known manuscripts in Hume's handwriting, broadly divisible into three categories: letters, non-epistolary documents (checks, receipts), and literature. ${ }^{25}$ Letters constitute the bulk of these manuscripts (ca. 650 items), although the total number of extant letters attributable to Hume (ca. 800 items) includes letters in the hands of amanuenses or later copyists, and at least seventy-three letters that have survived on the basis of transcriptions from lost or non-locatable autographs. A recent census of Hume's known letters runs to 796 items, with the following annual distribution:

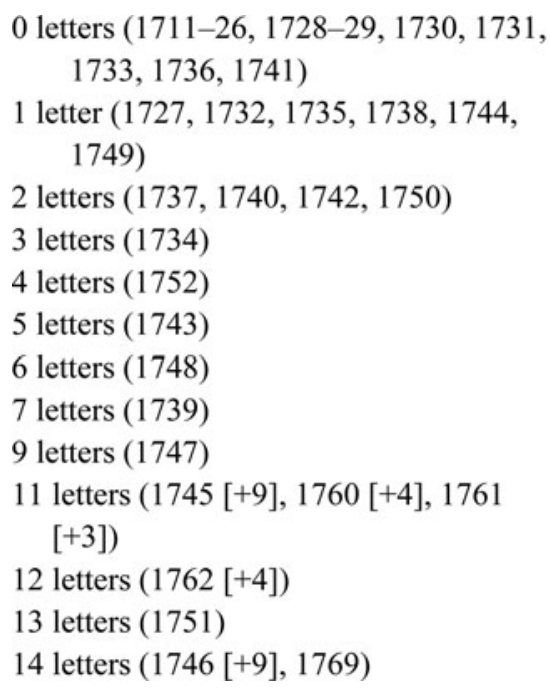

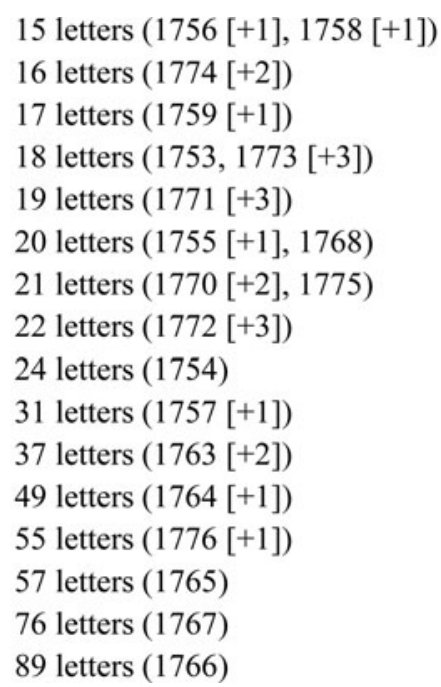

Figure 1-Census of Hume's Known Letters. Source: Hume, Further Letters of David Hume, 236-37. Note the use of $[+x]$ following a year indicates the number of undated letters that may conjecturally be assigned to the year.

Two aspects of these statistics deserve emphasis: the exiguity of material from Hume's early life (only eighteen letters survive from the years 1711-1740) and the practice of ascribing letters to Hume, notwithstanding the absence of an extant manuscript. These issues have created significant difficulties for the scholarship of Hume's early correspondence, sparking controversies over the dating of fragmentary letters and prising open a space for the intrusion of forgeries and spuria. There are comparable problems in the bibliography of Hume's works, involving the surmised attribution of anonymous publications. In those cases, the allegation of authorship has often turned on Hume's style, ${ }^{26}$ suggestive passages in his correspondence, ${ }^{27}$

\footnotetext{
${ }^{25}$ For these categories, see Hume, Further Letters of David Hume, 139-41.

${ }^{26}$ Paul H. Meyer, "Voltaire and Hume's Descent on the Coast of Brittany," Modern Language Notes 66, no. 7 (1951): 429-35; David Raynor, "Hume and Robertson's History of Scotland," Journal for EighteenthCentury Studies 10, no. 1 (1987): 59-63; David Raynor, "Hume's Critique of Helvétius' De l'Esprit," Studies on Voltaire and the Eighteenth Century 215 (1982): 223-29.

${ }^{27}$ David Raynor, "Hume on Wilkes and Liberty: Two Possible Contributions to The London Chronicle," Eighteenth-Century Studies 13, no. 4 (1980): 365-76.
} 
or the controvertible recollection of a memoirist. ${ }^{28}$ In the most difficult instance, the attribution to Hume of a pamphlet on the Scottish militia, Sister Peg (1761), scholars have had to contend against Hume's apparent confession that he authored the work himself, in spite of the mass of evidence that has pointed, insistently, to Adam Ferguson (1723-1816). ${ }^{29}$ In principle, the attribution of letters and manuscripts should depend on the use of similar canons of evidence-the style and provenance of the item or any corroborative reference to the item in ancillary documentation-alongside the supposedly decisive congruence of the item's handwriting with "incontestable" specimens of Hume's autograph. Yet even handwriting can prove resistant to comparison. The problem is acute in the case of a Hume manuscript sold by Sotheby's in 1988 without a verifiable provenance in its advertisement: a manuscript copy of university lectures on "fluxions" (infinitesimal calculus) given by George Campbell (d. 1766) at the University of Edinburgh in 1726, supposedly transcribed in Hume's "early" handwriting. ${ }^{30}$ The absence of a provenance for the manuscript and its postsale exportation to Japan have compounded the more basic challenges facing a scholar wishing to compare the handwriting in the manuscript with specimens from a determinately proximate era-only four of which exist. ${ }^{31}$

Other cases point to the difficulty in seeing past irregular forms of handwriting, where the provenance and content of a manuscript otherwise align with a scholar's expectations. In 1953, A. N. L. Munby, the librarian of King's College, Cambridge was shown an unpublished letter (figure 2), purportedly in Hume's handwriting, by Edith Margaret Chrystal, a Fellow of Newnham College. The letter, dated 16 January 1754, was addressed to "William Creech Esquire I Publisher and Printer," and signed "David Hume | From my house, James Court." Ernest Campbell Mossner included the letter in his and Klibansky's New Letters, ${ }^{32}$ but only after he had privately contacted Munby to question its discordances: the handwriting in the letter did not resemble Hume's from 1754 or any other period; the addressee of the letter, supposedly the publisher William Creech (1745-1815), was implausibly young in 1754; and the valediction of the letter, "From my house, James Court," defied the

${ }^{28}$ David Raynor, "Hume's Abstract of Adam Smith's Theory of Moral Sentiments," Journal of the History of Philosophy 22, no. 1 (1984): 51-79; D. D. Raphael and Tatsuya Sakamoto, "Anonymous Writings of David Hume," Journal of the History of Philosophy 28, no. 2 (1990): 271-81.

${ }^{29}$ For this attribution, see [David Hume], Sister Peg: A Pamphlet Hitherto Unknown by David Hume, ed. David Raynor (Cambridge, 1982) and the reviews of Raynor's edition by Roger L. Emerson, Hume Studies 9, no. 1 (1983): 74-81 and Richard Sher, Philosophical Books 24, no. 2 (1983): 85-91.

${ }^{30}$ For this manuscript (inscribed "A Treatise of Fluxions, by Mr. George Campbell: Professor of Mathematicks in Edinburgh, Written by David Home, 1726"), see M. A. Stewart, introduction to Studies in the Philosophy of the Scottish Enlightenment, ed. M. A. Stewart (Oxford, 1990), 1-10, at 8-9.

${ }^{31}$ For extant specimens of Hume's autograph ca. 1711-31, see Hume's signature of matriculation, 27 February 1723, INl/ADS/STA/2/2, p. 62, Edinburgh University Archives, cited in M. A. Stewart, "Hume's Intellectual Development," in Impressions of Hume, ed. M. Frasca-Spada and P. J. E. Kail (Oxford, 2005), 11-58, at 16n17; a copy of Justin, Historiae Philippicae (Leiden, 1701), inscribed "David Home His Book 1723 March 6 Edinburgh," JA3285, Edinburgh University Library; a copy of the third Earl of Shaftesbury, Characteristicks of Men, Manners, Opinions, Times (London, 1723), inscribed "David Home 1726," B1385.A2 1723 v. 1-3, University of Nebraska Library, Lincoln; and a letter from Hume to Michael Ramsay, 4 July 1727, NLS, MS 23152.17, printed in Hume, The Letters of David Hume, $1: 9-11$.

${ }^{32}$ Hume, New Letters of David Hume, 229-30. 


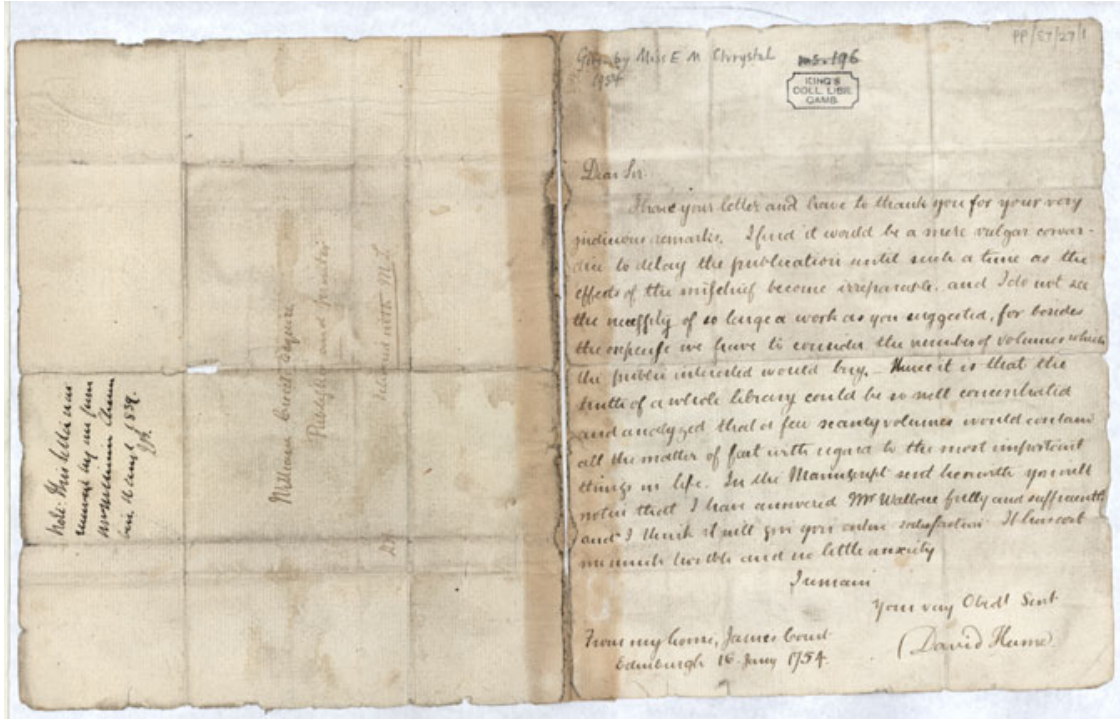

Figure 2-A forged letter, dated 16 January 1754, attributed to Hume. JMK/PP/87/27/1, King's College Archive Centre, Cambridge.

known date of Hume's move to James Court, Edinburgh, by eight years. ${ }^{33}$ Notwithstanding these difficulties, Mossner concluded that the manuscript was authentic: the signature resembled Hume's; the direction to William Creech, supposedly in a different hand from the remainder of the letter, was merely the interpolated guesswork of a later collector; and the address, "James Court," agreed with the dating and address in two sets of manuscript memoranda attributed to Hume, in the Huntington Library and the National Library of Scotland (figure 3). ${ }^{34}$ Mossner was convinced that Hume's letter had actually been addressed to Andrew Millar (1705-68), Hume's publisher, and transcribed "in the hand of a clerk"-a practice that Hume had never otherwise adopted. ${ }^{35}$

In their correspondence, Munby and Mossner had contemplated the possibility that the "Creech letter" was a forgery. Munby confessed that it "would be difficult to see for what purpose such a document could be forged," and Mossner agreed: "The theory of forgery I took, like yourself, little stock in from the beginning." 36 This confidence in the purposelessness of a forgery was understandable. Unlike other forgeries, insinuated into the historical record as jeux d'esprit for the amusement of collectors, or as an arrogation of an author's intellectual authority, the "Creech letter" was neither amusing nor intellectually useful; it referred to matters that were impossible to explicate. In 1979, however, Alan Bell discovered that the

${ }^{33}$ Hume, New Letters of David Hume, 230n3.

${ }^{34}$ MS 12263, Huntington Library, San Marino; NLS, MSS 732-4.

${ }^{35}$ Hume, New Letters of David Hume, 229nl.

${ }^{36}$ For Munby's correspondence with Mossner, see JMK/PP/87/27/2-9, King's College Archive Centre, Cambridge. 
historical memoranda used by Mossner as a form of substantiation for his surmise about the letter were the handiwork of Alexander "Antique" Smith (1859-1913), the prodigious Scottish forger, who had sold several faked manuscripts on the British autograph market in the 1880s and 1890s. ${ }^{37}$ On closer inspection, the "Creech letter" was a collateral fake, produced by Smith with the same misdated place of origin ("From my house, James Court") and the same characteristic flaws in handwriting and vocabulary.

Mossner's failure to recognize Smith's work was an explicable lapse when set against the transmission of an otherwise pristine corpus of manuscripts in Hume's handwriting. Unlike other Nachlässe, such as Tobias Smollett's, Hume's was free of demonstrated or alleged forgeries. ${ }^{38}$ Instead, when manuscripts in Hume's autograph were discovered, they rarely exhibited the irregularities of a counterfeit or interpolation. ${ }^{39}$ In 1958, a letter of 1735 from Hume to James Birch, written from La Flèche, was sold by Goodspeed's Book Shop, Boston, purchased by the University of Texas at Austin, and published by Mossner. ${ }^{40}$ The letter provided an invaluable glimpse of Hume's life during the period in which he wrote $A$ Treatise of Human Nature, and it had appeared with an unpublicized provenance in an unusual location. Any skepticism that might have arisen about this immensely important letter could be answered with reference to its unobjectionable content, handwriting, orthography, and paper. In 1963, Tadeusz Kozanecki announced his discovery of five letters in Hume's hand, dated between 1737 and 1776, in the Czartoryski Museum, Krakow, where they were preserved as a gift to Princess Izabela Czartoryska (1746-1835) from Hume the Younger, who had met Czartoryska during her tour of Scotland in 1790. The earliest letter, addressed to Hume's close friend Michael Ramsay (d. 1774), provided an extraordinary reference to Hume's philosophical reading during his stay in La Flèche, in a manner unparalleled by any other extant item of Hume's correspondence. In describing his philosophical writing, Hume encouraged Ramsay to "read once over le Recherche de la Verité

\footnotetext{
${ }^{37}$ For these forgeries, see Alan Bell, "Some Spurious Hume Documents," Notes and Queries 26, no. 6 (1979): 561; M. A. Stewart, "The Dating of Hume's Manuscripts," in The Scottish Enlightenment. Essays in Reinterpretation, ed. Paul Wood (Rochester, 2000), 267-314, at 269, 309.

${ }^{38}$ For the forgery of Smollett's manuscripts, see Lewis M. Knapp et al., "English Literature, 16601800: A Current Bibliography," Philological Quarterly 30 (1951): 225-307, at 289-91; Allen T. Hazen et al., "English Literature, 1660-1800: A Current Bibliography," Philological Quarterly 31 (1952): 225314, at 299-300; Lewis M. Knapp and Lillian de la Torre, "Forged 'Smollett' Letter," Modern Language Quarterly 14, no. 2 (1953): 228; Miguel de Cervantes Saavedra, The History and Adventures of the Renowned Don Quixote Translated by Tobias Smollett, ed. Martin C. Battestin and O. M. Brack, Jr. (Athens, GA, 2003), xlvnl3.

${ }^{39}$ For a controvertible exception, see R. W. Connon, "A Treatise of Human Nature," Times Literary Supplement, 4 April 1975, 28; R. W. Connon, "John Payne Collier," Times Literary Supplement, 8 July 1983, 729, referring to British Library C.175. c.8, a Sammelband of volume 3 of the Treatise and Hume's Abstract of the Treatise, bearing emendations that Connon had attributed to Hume himself-R. W. Connon, "Some MS Corrections by Hume in the Third Volume of His Treatise of Human Nature," Long Room 11 (1975): 14-22; R. W. Connon, "Some Hume MS Alterations on a Copy of the Abstract," Journal of the History of Philosophy 14, no. 3 (1976): 353-56-only later to speculate that the emendations might have been the work of John Payne Collier (1789-1883), the "scholar forger."

${ }^{40}$ Ernest Campbell Mossner, "Hume at La Flèche, 1735: An Unpublished Letter," Texas Studies in English 37 (1958): 30-33. For the provenance of this item, see the acquisition notes for the letter in the David Hume Collection, Harry Ransom Center, University of Texas at Austin.
} 


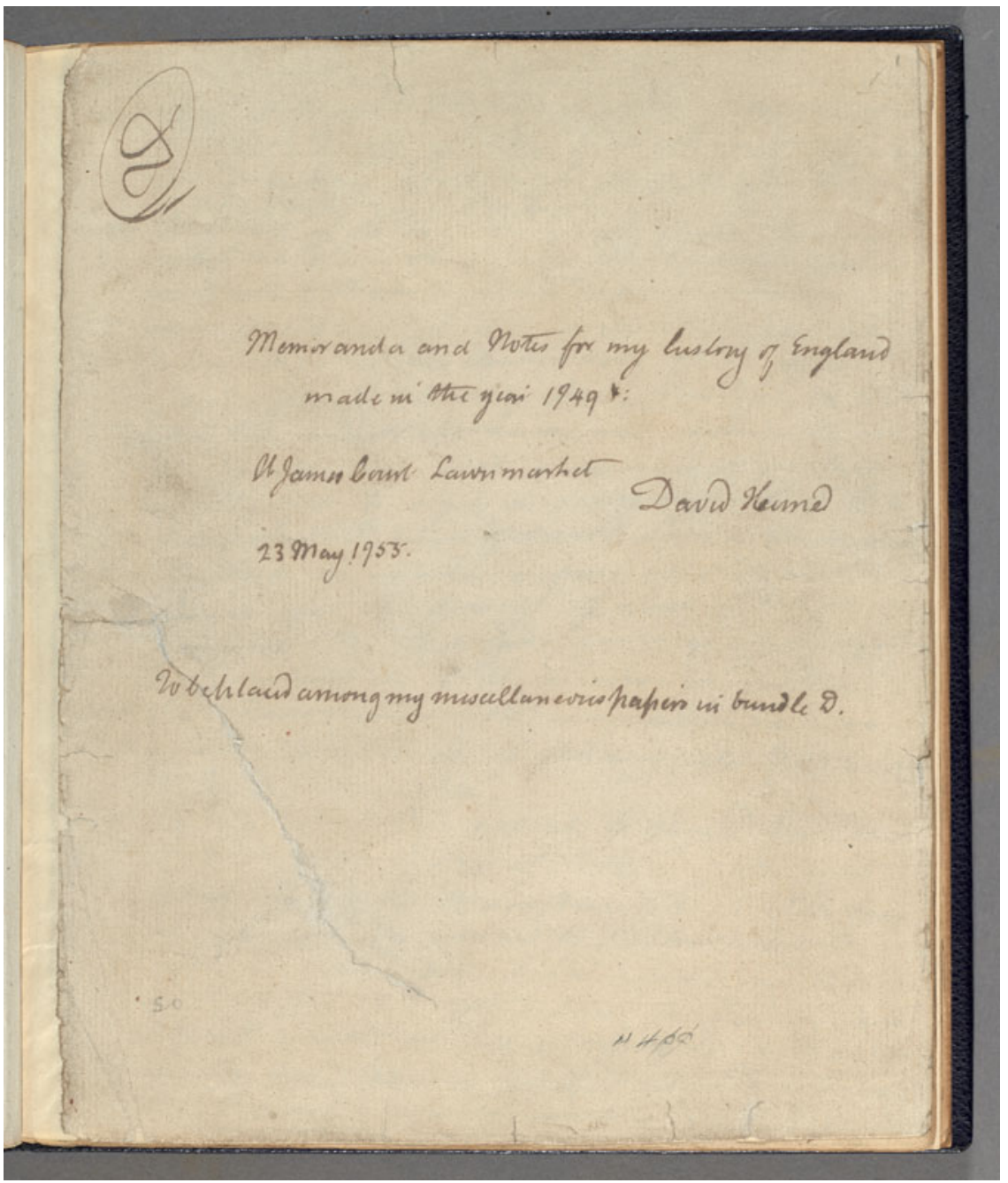

Figure 3-A page of forged historical memoranda, dated 23 May 1755, attributed to Hume. MS 12263, fol.1r, Huntington Library.

of Pere Malebranche, the Principles of Human Knowledge by Dr Berkeley, some of the more metaphysical Articles of Bailes Dictionary ... [and] Des-Cartes Meditations." "These books," Hume added remarkably, "will make you easily comprehend the metaphysical Parts of my Reasoning." 41 This manuscript, recovered against scholarly expectations in another unusual location, was particularly susceptible of skepticism about its authenticity, since it provided a solution ex machina to a

41 Tadeusz Kozanecki, "Dawida Hume' a nieznane listy w zbiorach Muzeum Czartoryskich (Polska)," Archiwum Historii Filozofi i Myśli Spotecznej 9 (1963): 127-41, at 133-34. For the provenance of these letters, see Jacopo Agnesina, "Lettere di David Hume conservate presso la Princess Czartoryski Library di Cracovia," Giornale Critico della Filosofia Italiana 98, no. 1 (2019): 102-27, at 103n7, 113n33. 
debate commenced by Richard Popkin in 1959 surrounding Hume's knowledge of Berkeley's "idealism." Without the evidence provided by Kozanecki, Popkin had insisted that the evidence for Hume's familiarity with Berkeley's works was reducible to three nebulous references in Hume's A Treatise of Human Nature, Philosophical Essays Concerning Human Understanding (1748) and his essay "Of National Characters" (1748). ${ }^{42}$ Yet the manuscript was verifiably Hume's, on the same basis as the Goodspeed's letter of 1735: its content, handwriting, orthography, and paper.

Within this narrative of discovery, the conceit of Michael Morrisroe's submissions to the Philological Quarterly and English Studies was unremarkable. Two letters by Hume had lain hidden in private collections since the eighteenth century and they were now brought to light by the activities of an inquisitive scholar. In his introductions to both articles, Morrisroe provided an overview of the significance of his discoveries for existing and prospective research on Hume's life and thought. The letter to Millar showed that Hume "actually did begin gathering works on the subject of ecclesiastical history" in 1765, when scholars had otherwise "dismisse[d] the thought entirely." 43 The letter to Ramsay of 1734 reinforced the case against Popkin. Hume refers again to his familiarity with "the Principles of Human Knowledge by Dr Berkeley." 44 Yet where Kozanecki's discovery had shown that Hume was merely familiar with Berkeley's Principles, the letter discovered by Morrisroe referred explicitly to Hume's repeated "reading" of the same work. Unlike Hume's letter of 1737, which had allowed others to quibble over his direct or mediated knowledge of Berkeley's philosophy, ${ }^{45}$ this "conclusive proof" was not "rebuttable." 46 In Morrisroe's judgment, his discovery revealed that there could be "no doubt" that Hume had read Berkeley.

\section{MORRISROE'S DISCOVERIES}

Morrisroe was born in 1939. He completed his doctorate in English at the University of Texas at Austin in 1966, after degrees from Manhattan College and the University

${ }^{42}$ Richard H. Popkin, "Book Reviews," Journal of Philosophy 56, no. 2 (1959): 67-71, at 71; Philip P. Wiener, "Did Hume Ever Read Berkeley?," Journal of Philosophy 56, no. 12 (1959): 533-35; Richard H. Popkin, "Did Hume Ever Read Berkeley?," Journal of Philosophy 56, no. 12 (1959): 535-45; Ernest Campbell Mossner, "Did Hume Ever Read Berkeley? A Rejoinder to Professor Popkin," Journal of Philosophy 56, no. 25 (1959): 992-95; Antony Flew, "Did Hume Ever Read Berkeley?," Journal of Philosophy 58, no. 2 (1961): 50-51; Philip P. Wiener, "Did Hume Ever Read Berkeley?," Journal of Philosophy 58, no. 8 (1961): 207-9; Richard H. Popkin, "So, Hume Did Read Berkeley," Journal of Philosophy 61, no. 24 (1964): 773-78.

${ }^{43}$ Morrisroe, Jr., "Hume's Ecclesiastical History" 432.

${ }^{44}$ Morrisroe, Jr., "Did Hume Read Berkeley?," 314.

45 Roland Hall, "Did Hume Read Some Berkeley Unawares?,” Philosophy 42, no. 161 (1967): 276-77; Roland Hall, "Hume's Actual Use of Berkeley's Principles," Philosophy 43, no. 165 (1968): 278-80; Graham P. Conroy, "Did Hume Really Follow Berkeley?," Philosophy 44, no. 169 (1969): 238-42; Roland Hall, "Yes, Hume Did Use Berkeley," Philosophy 45, no. 172 (1970): 152-53. For a summary of this debate, see Richard H. Popkin, "Intellectual Autobiography: Warts and All," in The Sceptical Mode in Modern Philosophy: Essays in Honour of Richard H. Popkin, ed. Richard A. Watson and James E. Force (Dordrecht, 1988), 103-49, at 132-33.

${ }^{46}$ Morrisroe, Jr., "Did Hume Read Berkeley?," 314. 
of Alabama. His doctoral committee consisted of his supervisor, Ernest Campbell Mossner, and three other members of the departments of English and philosophy: Joseph E. Slate (1927-2014), David J. DeLaura (1931-2005), and Frederick H. Ginascol (d. 1999). The subject of Morrisroe's doctoral dissertation was Hume's use of rhetoric in the Dialogues Concerning Natural Religion and the other dialogic passages in Hume's works; the preface to the dissertation described its argument as an attempt "to show how the dialogues, especially the Dialogues Concerning Natural Religion, evidence Hume's ability to present difficult and controversial concepts to a potentially hostile reader in such a way that the hostility of the reader is mitigated while his intellectual horizons are expanded." 47 This argument was reiterated in articles that Morrisroe completed for two academic journals, ${ }^{48}$ and in a contribution to Mossner's Festschrift, published conjointly by the University of Texas at Austin and the University of Edinburgh in $1974 .{ }^{49}$ Soon after completing his doctorate, Morrisroe was appointed as an assistant professor of English at the University of Illinois, Chicago Circle. ${ }^{50} \mathrm{He}$ stayed in this post for at least five years (1967-1972) and offered such courses as "The Eighteenth-Century Novel" (fall 1967), "Introduction to Fiction" (spring 1970), and "English Prose of the Eighteenth Century" (spring 1971)..$^{51}$ In the same period (1967-1970), Morrisroe completed a JD at John Marshall Law School. In 1969, he published an article in the school's Journal of Practice and Procedure, ${ }^{52}$ and he was soon after admitted to practice as an attorney by the Illinois Supreme Court. ${ }^{53}$ There is no record of Morrisroe's employment as an assistant professor of English at the University of Illinois after 1973, but he appears to have retained a significant interest in eighteenth-century literature for the remainder of the decade. In 1970, he founded Enlightenment Essays, a periodical that he edited until 1980, which would publish dozens of short articles by numerous contributors, including two articles and several book reviews by Morrisroe himself. ${ }^{54}$ In the

\footnotetext{
${ }^{47}$ Michael Morrisroe, Jr., "The Rhetoric of the Dialogues of David Hume” (PhD diss., University of Texas at Austin, 1966), iv.

${ }^{48}$ Michael Morrisroe, Jr., "Hume's Rhetorical Strategy: A Solution to the Riddle of the Dialogues Concerning Natural Religion," Texas Studies in Literature and Language 11, no. 2 (1969): 963-74; Michael Morrisroe, Jr., "Rhetorical Methods in Hume's Works on Religion," Philosophy and Rhetoric 2, no. 3 (1969): 121-38.

${ }^{49}$ Michael Morrisroe, Jr., "Linguistic Analysis as Rhetorical Pattern in David Hume," in Hume and the Enlightenment: Essays Presented to Ernest Campbell Mossner, ed. William B. Todd (Edinburgh and Austin, 1974), 72-82.

${ }^{50}$ For a record of Morrisroe's employment, see University of Illinois, Transactions of the Board of Trustees, 19 April 1967, 477; 20 March 1968, 956; 18 February 1970, 781; 18 March 1970, 854; 17 February 1971, 208.

${ }^{51}$ I am grateful to Scott Pitol, university archivist of the University of Illinois at Chicago (formerly Chicago Circle) for his research into the university's schedules and course catalogues between 1967 and 1973.

${ }^{52}$ Michael Morrisroe, Jr., "Expanding Application of the Special Legislation Clause of the Illinois Constitution," John Marshall Journal of Practice and Procedure 3, no. 1 (1969): 96-117.

${ }^{53}$ For Morrisroe's admission to practice, see the Illinois Attorney Registration and Disciplinary Commission database, accessed 9 March 2019, https://www.iardc.org/lawyersearch.asp.

${ }^{54}$ Michael Morrisroe, Jr., "Characterization as Rhetorical Device in Hume's Dialogues Concerning Natural Religion," Enlightenment Essays 1, no. 2 (1970): 95-107; Michael Morrisroe, Jr., "Ciceronian, Platonic, and Neo-Classic Dialogues: Forms in Berkeley and Hume," Enlightenment Essays 3, nos. 3/4 (1972): 147-59. Morrisroe contributed book reviews to many issues of the journal: Enlightenment Essays 1, no. 1 (1970): 70-1; Enlightenment Essays 2, no. 1 (1971): 54-56; Enlightenment Essays 2, no. 2 (1971): 125-26;
} 
years since their first appearance, Morrisroe's contributions to eighteenth-century scholarship have attracted a measure of commentary and approbation from several Hume specialists and historians of philosophy. ${ }^{55}$

In reporting his discovery of two Hume manuscripts, Morrisroe had every confidence that his claims would be received seriously, as one might expect for a faculty member at a prominent university who had studied under the world's foremost expert on Hume's life and circle and who now served as editor-in-chief of a respectable academic periodical. ${ }^{56}$ Questions could be raised about Morrisroe's failure to publish a facsimile of the manuscripts, but this might also be said to have surpassed the reasonable expectations of contemporary peer reviewers or readers. Researchers, as much today as in 1972-73, are not always in a position to arrange for the photographic reproduction of manuscripts, particularly when the request might offend the preferences of a private owner. Other scholars had transcribed Hume's manuscripts in private collections without publishing facsimiles and their practice had not provoked suspicion. In 1962, Mossner himself had published seventeen letters from Hume to Patrick Murray (1703-1778), Lord Elibank, without identifying their owner or location and without photographic evidence in corroboration. ${ }^{57}$ Any difficulty surrounding the absence of a facsimile or consultable originals could be obviated by a presumption of Mossner's good faith, particularly when this presumption was combined with a plausible account of the letters' past and present ownership.

In both articles, Morrisroe reported the provenance of his discoveries as follows:

\section{Letter 1 (Philological Quarterly)}

I am grateful to the late Ronald $\mathrm{H}$. Miller, administrator de bonis non, cum testamento annexo, of the estate of Patrick J. Kelly, City of Chicago, County of Cook, State of Illinois, for permission to make a typescript of this letter and to publish it for scholarly

Enlightenment Essays 2, no. 3-4 (1971): 222-3; Enlightenment Essays 3, no. 1 (1972): 66-67; Enlightenment Essays 3, no. 2 (1972): 139-41; Enlightenment Essays 4, no. 1 (1973): 57-58.

${ }_{55}$ R. H. Carnie, "The Hume-Hailes Relationship," Forum for Modern Language Studies 14, no. 4 (1978): 289-303, at 303n46; Peter Walmsley, The Rhetoric of Berkeley's Philosophy (Cambridge, 1990), 82; Paula Wood Brown, "The Unnatural Aspects of Natural Religion Revealed: A Skeptical Reader's Response to Hume's Dialogues," Studies in Eighteenth-Century Culture 22 (1993): 269-80, at 269; Peter Dendle, "A Note on Hume's Letter to Gilbert Elliot," Hume Studies 20, no. 2 (1994): 289-91, at 290; Martin Bell, "The Relation between Literary Form and Philosophical Argument in Hume's Dialogues Concerning Natural Religion," Hume Studies 27, no. 2 (2001): 227-46, at 243n3; William Lad Sessions, Reading Hume's Dialogues: A Veneration for True Religion (Bloomington, 2002), 1; Thomas Olshewsky, "Demea's Dilemmas," British Journal for the History of Philosophy 11, no. 3 (2003): 473-92, at 473; Rich Foley, "Unnatural Religion: Indoctrination and Philo's Reversal in Hume's Dialogues Concerning Natural Religion," Hume Studies 32, no. 1 (2006): 83-112, at 95.

${ }^{56}$ William R. Kupersmith, an assistant editor at the Philological Quarterly in 1973, has recalled in private correspondence (5 August 2017) that Morrisroe's submission was probably accepted by the journal after internal peer review by the journal's "staff" or peer review by a "Hume specialist" in the department of philosophy at the University of Iowa. The archive of English Studies in Radboud Universiteit, Nijmegen, does not preserve any records pertaining to Morrisroe's submission.

${ }^{57}$ Ernest Campbell Mossner, "New Hume Letters to Lord Elibank, 1748-1776," Texas Studies in Language and Literature 4, no. 3 (1962): 431-60. For the subsequent sale of many of these letters, see Sotheby's, London, Catalogue of Valuable Printed Books, Oriental Drawings, Autograph Letters and Historical Documents, catalogue, 29 November 1971, lot 169. 
purposes. The letter is one of a collection of forty-seven letters by eighteenth-century personages. Sold by the estate through brokerage auction, the present location of the letters is unknown. ${ }^{58}$

\section{Letter 2 (English Studies)}

I am grateful to the late R. H. Miller, esq., administrator de bonis non cum testamento annexo of the estate of P. J. Kelly for permission to make a typescript of the letter. It is my belief that the letter was subsequently purchased for the New York Morris Collection. ${ }^{59}$

Where Hume's letters are accessible in public or private collections, their provenance is rarely of significance to the purposes of a researcher. Yet the location of the letters published by Morrisroe and the identity of their owners remain unknown-and the provenances above are the only clues we now possess to the mystery of the letters' fate after 1972-73.

Both are credible provenances: Morrisroe was apprised by a man named Ronald H. Miller that the estate of Patrick J. Kelly of Chicago, Illinois, preserved two letters by Hume; Miller was Kelly's executor, appointed de bonis non cum testamento annexo (that is, on the death of the decedent's original executor); the letters were sold at "brokerage auction" as part of a larger collection of eighteenth-century manuscripts; and one of the letters may subsequently have entered the "Morris Collection" of New York. There are several inferences that can supplement these details. The first is that Kelly had died in Chicago within two or three years of the publication of Morrisroe's article in 1972, or Morrisroe's arrival in Chicago. In Morrisroe's curriculum vitae, dated August 1966 and appended to the typescript of his doctoral dissertation, he notes that he "plan[ned] to reside" in Chicago "upon his graduation from The University of Texas," and he does not refer to a pre-existing connection to Chicago or Illinois. The second inference is that Miller had also died in Chicago, and that he had practiced as an attorney in the state of Illinois-a claim that must arise from Morrisroe's use of the post-nominal courtesy "esq." in reference to Miller. The final inference is that the deaths of Kelly and Miller would have been recorded in probate records in Cook County. It would also be reasonable to assume that Miller's admission to the Bar of Illinois would be recoverable from court or bar records, and-if he were not admitted in Illinois - that his appointment as an executor would be documented in probate proceedings, in accordance with a provision in Illinois state law ca. 1972 requiring the appointment of non-resident executors de bonis non cum testamento annexo to be approved by a probate court. ${ }^{60}$

A number of objections could be raised against these inferences. It is possible, for example, that Kelly's estate was subjected to protracted legal wrangling, and that Kelly himself had died decades before 1972. It is possible that Morrisroe's use of "esq." to refer to Miller was an extraneous courtesy rather than a reference to Miller's profession. It is possible that Kelly and Miller had resided in Chicago and died elsewhere; the reportage of their deaths, and the administration of their

${ }^{58}$ Morrisroe, Jr., "Did Hume Read Berkeley?," 314n30.

${ }^{59}$ Morrisroe, Jr., "Hume’s Ecclesiastical History" 432n10.

${ }^{60}$ William M. James, Illinois Probate Law and Practice, vol. 3, Sections 75-130 (Chicago, 1951-52), 67-68 (\$77); Austin Fleming, James Illinois Probate Law and Practice, vol. 3, Sections 75-130. 1975 Pocket Parts (St. Paul, 1975), 17-18 (\$77). 
estates, would be recorded outside Chicago or Illinois. These are all reasonable objections, which are unanswerable: the details of the provenances are not exact enough to scrutinize. Yet the following are worth stating: the Supreme Court of Illinois and the standard directories of legal practitioners in Illinois (Sullivan's Law Directory and Martindale-Hubbell) possess no record of an attorney named Ronald H. Miller at any time during the twentieth century; the probate archives of the Cook County Clerk of Court possess no record for the death of an individual named Ronald H. Miller between 1964 and 1974 or the appointment of such an individual as an administrator de bonis non cum testamento annexo; the same archives do not possess a record for the death of a Patrick J. Kelly between 1964 and 1974; and no reference can be found to a relevant "Morris Collection" of books, manuscripts, or literary material in New York.

These difficulties may be explicable. In addition to the explications mentioned above, it is possible that elements of the provenance were misreported by Morrisroe or intentionally distorted, at the request of Miller or an unnamed third party. Leaving aside either concession, however, the questionable contents of the letters raise significant objections of their own. Both letters are transcribed below, with the addition of superscript capital letters, which will be used for reference in the discussion that follows:

Letter 1-Hume to Michael Ramsay, 29 September 1734

${ }^{\text {A }}$ Rheims. Sep ${ }^{\mathrm{t}} .29$ 1734. N.S. ${ }^{\mathrm{A}}$

Dear Michael

It was with mild Surprize that I receiv'd your Letter ${ }^{\mathrm{B}}$ dated $a t^{\mathrm{B}}$ London. I hope that the Business which you ${ }^{C}$ writ of ${ }^{C}$ in the Postscript will be concluded with such Benefits to Both Partys as you expect. It is with an ${ }^{\mathrm{D}}$ Abundance of Pleasure ${ }^{\mathrm{D}}$ that I contemplate the Success of your ${ }^{\mathrm{E}}$ Undertaking ${ }^{\mathrm{E}}$. The Letter ${ }^{\mathrm{F}}$ requested of ${ }^{\mathrm{F}}$ me is enclos'd.

${ }^{\mathrm{G}} \mathrm{I}$ am resolved ${ }^{\mathrm{G}}$ before the ${ }^{\mathrm{H}}$ post go away ${ }^{\mathrm{H}}$ to tell you of the Library to which I am admitted here in Rheims. I was recommended to the Abbé Noel-Antoine Pluche, which most learned man has opened his fine Library to me. It has all ${ }^{\mathrm{I}}$ Advantages for Study ${ }^{\mathrm{I}}$ and particularly holds an Abundance of Writings of both the French and English along with as complete $\mathrm{a}^{\mathrm{J}}$ selection ${ }^{\mathrm{J}}$ of the Classics as I have seen in one place. It is my Pleasure to read over again today ${ }^{\mathrm{K}}$ Locke's Essays ${ }^{\mathrm{K}}$ and the ${ }^{\mathrm{L}}$ Principles of Human Knowledge by Dr. Berkeley ${ }^{\mathrm{L}}$ which are printed in their ${ }^{\mathrm{M}}$ original state ${ }^{\mathrm{M}}$ and in French copy. I was told by a student from the University who attends to the order of the Library that his Master received new works of Learning \& Philosophy from London and Paris each month, and so I shall feel no want of the latest books.

We shall expect Success from your Undertaking and await your Letter with Curiosity. Your affectionate Friend,

D. H. ${ }^{61}$

Letter 2-Hume to Andrew Millar, 26 August 1765

Dear Sir

I am much obligd to you for the Copy of Fitz-Osborne's Letters. It was received in

${ }^{61}$ Morrisroe, Jr., "Did Hume Read Berkeley?," 314-15. 
good order at ${ }^{\mathrm{N}}$ Lord Hallifax's Office. ${ }^{\mathrm{N}}$ You are again anxious after my ecclesiastical History. The Reports that you hear should be ${ }^{\mathrm{O}}$ put aside ${ }^{\mathrm{O}}$ as you know the facts of the matter and my resolve never to undertake a History which wou'd expose me again to ${ }^{\mathrm{P}}$ Impertinence \& Ill-manners. ${ }^{\mathrm{P}}$ The Prejudices of all factions have not so far subsided that a History wrote with a Spirit of Impartiality could withstand the Rage \& Clamor. ${ }^{\mathrm{Q}}$

I have, however, been gathering most of the Works of Authors in France and England of the History of the Church, and I should be glad if I have the Leizure to read over them. ${ }^{\mathrm{R}}$ An Account of some Periods in ecclesiastical History might be put beyond Controversy, and if one Volume were successful then the others might be composed: But I do not think it so near a Prospect. ${ }^{\mathrm{R}}$

I send you enclosd ${ }^{\mathrm{s}}$ a Bill on $\mathrm{Mr}$ Coutts $^{\mathrm{s}}$ for 3 pounds four Shillings, which after adding the Price of the Letters is the Ballance I owe you. My Compliments to Mrs Millar. I am Dear Sir

Your most obedient Servant

David Hume ${ }^{62}$

In phrasing and vocabulary, the letters are prima facie indistinguishable from other products of Hume's pen. Indeed, the addressees, Michael Ramsay and Andrew Millar, Hume's publisher, were recipients of other letters in which Hume adopted similar or identical phrasing. The form of date used in Letter 1 (superscript A), and the phrase "dated at" (B), are identical to Hume's forms and wording in another letter to Ramsay of 12 September 1734.63 The phrase "writ of" (C) is used only once again in Hume's extant letters, manuscripts, and publications, in a letter to Ramsay of 4 July 1727.64 The phrase "post go away" $(\mathrm{H})$ also appears only once again, in the aforementioned letter to Ramsay of 12 September $1734 .{ }^{65}$ In Letter 2, the phrases "Impertinence \& Ill-manners" (P) and "a Bill on $\mathrm{Mr}$ Coutts" (S) appear uniquely in a letter to Millar of 14 January 1765.66 Similarly, the phrase "Lord Hallifax's Office" $(\mathrm{N})$ appears uniquely in a letter to Millar of 4 May 1765.67 Other phrases appear uniquely in letters to different correspondents: "Abundance of Pleasure" (D) and "Advantages for Study" (I) appear in a letter from Hume to his childhood friend James Birch of 12 September $1734 .^{68}$ Then there are the phrases used by Hume on several different occasions: "I am resolved" (G) appears five times in Hume's extant letters, including in a letter to Ramsay of 3 July 1751;69 "near a Prospect" (R) appears twice in Hume's extant letters, including in a letter to Millar of 18 December 1759; "undertaking" (E) appears dozens of times, including in a letter to Ramsay of 22 February $1739 .{ }^{70}$ Even phrases with no exact matches in Hume's letters, such as "Rage \& Clamor" (Q), "put aside" $(\mathrm{O})$, or "requested of" $(\mathrm{F})$, approximate his wording in letters and writings on similar

\footnotetext{
${ }^{62}$ Morrisroe, Jr., "Hume's Ecclesiastical History," 432-33.

${ }^{63}$ Hume, The Letters of David Hume, 1:19.

${ }^{64}$ Hume, The Letters of David Hume, 1:9.

${ }^{65}$ Hume, The Letters of David Hume, 1:21.

${ }^{66}$ Hume, The Letters of David Hume, 1:491.

${ }^{67}$ Hume, The Letters of David Hume, 1:501.

${ }^{68}$ Hume, The Letters of David Hume, 1:22-3.

${ }^{69}$ Hume, The Letters of David Hume, 1:161-62, 178-79, 263-64, 300-1; 2:254-56.

${ }^{70}$ Hume, The Letters of David Hume, 1:316-18, 368-70.
} 
subjects. ${ }^{71}$ The effect is of a compelling symmetry between Morrisroe's two letters and Hume's stylistic inclinations. Yet there are also phrases that entirely defy Hume's practices and eighteenth-century conventions in general. The phrase "original state" $(\mathrm{M})$ does not appear in any of Hume's extant letters-and its apparent meaning, in reference to the original language or edition of a publication, is unattested in Hume's manuscripts and publications, and in optical-character-recognition searches of early-modern and eighteenth-century texts. ${ }^{72}$ The word "selection" (J) does not appear in any of Hume's extant letters, manuscripts, or publicationsand its apparent meaning, in reference to a number of items ("a selection of the Classics"), instead of the act of "selecting" ("my selection of a book"), is a solecism in English, ca. 1734. The first recorded use of "selection" in reference to a number of items in the Oxford English Dictionary ("selection," 2a) is dated 1805. ${ }^{73}$

Quite apart from stylistic considerations, the events described in both letters present several unaccountable divergences from the historical record. Letter 2 , in this respect, is less objectionable. It refers directly to a letter to Millar of 4 May 1765, first printed by Burton in 1846, ${ }^{74}$ in which Hume asks for a copy of William Melmouth the Younger's pseudonymous Letters on Several Subjects (1748-9) ("Fitz-Osborne's Letters") to be sent to the British embassy in Paris-Hume's place of residence between August 1763 and January 1766-via the office of George Montagu Dunk (1716-71), Lord Halifax, secretary of state for the Southern Department. Yet a number of other statements in the letter are curious. Hume has sent a payment to Millar, drawn on his account with Coutts Bank, which is not registered by Hume's extant customer account ledger. ${ }^{75}$ Hume has asked Millar to provide him with "most of the Works of Authors in France and England of the History of the Church," during the period of his appointment as chargé d'affaires to the British embassy (July-November 1765), when he could not reasonably have expected to commence work on a new historical project. Overlaying these incongruities is Hume's reuse of a phrasal combination that occurs, uniquely, in a

${ }^{71}$ For similar phrases to "Rage \& Clamor," see Hume, The Letters of David Hume, 1:5, 245-46; 2:8283, 199-201. For similar phrases to "put aside," see Hume, The Letters of David Hume, 1:13, 352; 2:14, 147. For "requested of," see David Hume, The History of England from the Invasion of Julius Caesar to the Revolution in 1688, ed. William B. Todd, 6 vols. (Indianapolis, 1983-1985), 4:239.

${ }^{72}$ These platforms include Google Books, InteLex Past Masters, Electronic Enlightenment, Early English Books Online, and Eighteenth Century Collections Online. Hume uses the phrase "original state" in reference to "the original state of nature" and "original state of rudeness and imperfection" in Hume, The History of England, 1:174, 2:521.

${ }^{73}$ The English Short Title Catalogue records a use approximating OED, "selection," 2a, in a book title from 1757, which may provide a terminus a quo for this signification: The Nonpareil; or, The Quintessence of Wit and Humour: Being a Choice Selection of those Pieces that Were Most Admired in the Ever-To-Be-Remember'd Midwife; or, Old Woman's Magazine (London, 1757).

${ }^{74}$ John Hill Burton, Life and Correspondence of David Hume (Edinburgh, 1846), 2:273; Hume, The Letters of David Hume, 1:491; Hume, Further Letters of David Hume, 204.

${ }^{75}$ For entries in Hume's ledger in the period January 1765-January 1766, see NLS, MS 3028, fols. 3v, $4 r-v, 5 r$, a facsimile of the relevant entries for Hume's account in the Coutts Bank Archive, London; the remaining entries in the ledger (terminating in December 1777) do not record any debit resembling the purported transaction in Morrisroe's text of Hume's letter to Millar, and the archive reportedly does not preserve any other documentation pertaining to Hume's transactions with the bank. In contrast, the transaction mentioned in Hume's letter to Millar of 14 January 1765 (Hume, The Letters of David Hume, 1:491), "a Bill on Mr Coutts for 12 pounds four shillings," is recorded on fol. $3 \mathrm{v}$. 
letter to Millar of 18 December 1759: "I fancy that I shall be able to put my Account of that Period of English History beyond Controversy. I am glad you have so near a Prospect of a new Edition." 76 Six years later, Hume expresses these sentiments in unusually similar terms (R): "An Account of some Periods in ecclesiastical History might be put beyond Controversy, and if one Volume were successful then the others might be composed: But I do not think it so near a Prospect." Although Hume was prone to the repetition of phrasing in letters sent on the same day and subject, ${ }^{77}$ verbatim repetition of multiple phrases after a hiatus of six years is startling. Finally, the fate of Hume's letters to Millar deserves notice: excepting one letter, preserved in the collection of James David Forbes (1809-68) in the University of St. Andrews, every extant letter from Hume to Millar is held within the Royal Society of Edinburgh's Hume bequest, owing-presumably-to the retrieval of the letters from Millar's family by Hume himself or Hume the Younger. ${ }^{78}$ It is certainly possible that a second letter escaped retrieval or was subsequently removed from the collection, but that such a letter would appear in Chicago in ca. 1972 is more vulnerable to disbelief, especially in the light of its several peculiarities in content and wording, its unverifiable provenance, and its absence from the standard indexes of manuscript sales in North America and the United Kingdom in the nineteenth and twentieth centuries. ${ }^{79}$

In comparison with the deficiencies in Letter 2, the knowledge of which require some familiarity with the arcana of Hume's finances and the posthumous custody of Andrew Millar's letters, those in Letter 1 reveal themselves under brief inspection. Hume refers implausibly to Locke's Essays (K), plural, when he must intend Essay, singular. ${ }^{80} \mathrm{He}$ reports that he has consulted a French translation of Berkeley's Principles of Human Knowledge, when a translation into French of Berkeley's Principles was not published until 1889. ${ }^{81}$ It could be answered that Hume had blundered in writing "Essays," or that he had erred in referring to a "French copy" of Berkeley's Principles. It could additionally, or alternatively, be answered that Morrisroe faltered in transcription: the unitalicized title of Berkeley's "Principles," in comparison with Locke's "Essays," suggests an absence of fidelity to the manuscript. These

${ }^{76}$ Hume, The Letters of David Hume, 1:316-17.

77 Hume, The Letters of David Hume, 2:63-64, 120-22.

${ }^{78}$ For these letters, see NLS, MS 23151.60-96; Papers of James David Forbes, msdep7, Autograph Collection, no. 10, University of St. Andrews Library. For Forbes's interest in Hume's manuscripts, see msdep7, Incoming Letters, nos. 14 (a, b), 44, and Letterbook 3, 234-35, University of St. Andrews Library, inventoried in R. N. Smart, An Index to the Correspondence and Papers of James David Forbes (1809-1868), and Also to Some Papers of His Son, George Forbes (St. Andrews, 1968), 18, 21.

${ }^{79}$ For Hume's presence in these indexes, see Waldmann, "Additions to Further Letters of David Hume"; Hume, Further Letters of David Hume, 216-31.

${ }^{80}$ Hume does not refer to Locke's Essay Concerning Human Understanding by name in any manuscript or publication. He refers instead to "Locke" or "Mr Locke"; see, for example, Hume, The Letters of David Hume, 1:39, 48, 201; David Hume, Essays Moral, Political, and Literary, ed. Eugene F. Miller, rev. ed. (Indianapolis, 1987), 91, 614; David Hume, An Enquiry Concerning the Principles of Morals: A Critical Edition, ed. Tom L. Beauchamp (Oxford, 1998), 91; David Hume, An Enquiry Concerning Human Understanding: A Critical Edition, ed. Tom L. Beauchamp (Oxford, 2000), 6, 16, 48, 61; David Hume, A Dissertation on the Passions and The Natural History of Religion: A Critical Edition, ed. Tom L. Beauchamp (Oxford, 2007), 272; David Hume, A Treatise of Human Nature, ed. David Fate Norton and Mary J. Norton (Oxford, 2007), 1:7, 28, 57, 408.

${ }^{81}$ T. E. Jessop and A. A. Luce, A Bibliography of George Berkeley (The Hague, 1973), 12. 
counterclaims are, once again, irrefragable. Yet one feature of the letter is impossible to attribute to Hume's misstatements or to Morrisroe's incompetence in transcription. Hume notes explicitly that Noël-Antoine Pluche is a resident of Reims and the owner of a "fine Library" in that city. Hume refers to a meeting with Pluche, in person, "which most learned man has opened his fine Library to me." These statements are either an astounding form of intentional mendacity on Hume's part or they are misinformed fabrications, characteristic of an inept forgery.

\section{REIMS, LÉVESQUE DE POUILLY, AND NOËL-ANTOINE PLUCHE}

The association of Hume with Reims arises from the survival of two letters, dated 12 September 1734, one addressed to James Birch and another to Michael Ramsay. The letters are the first surviving evidence of Hume's travels in France between 1734 and 1737, following his departure from Bristol, where he had worked-briefly and with apparent dissatisfaction-for a merchant. Hume's letter to Birch was first printed by Greig in 1932, after its sale by Sotheby's in March $1920 .{ }^{82}$ Hume's letter to Ramsay was first printed by Burton in $1846 .{ }^{83}$ In both letters, Hume refers to his arrival in Reims and the advice he had received in Paris from Andrew Michael Ramsay (1686-1743), the "Chevalier Ramsay," including a letter of recommendation "to a man"-residing in Reims- "who, they say, is one of the most learned in France." Hume does not identify this "man" and states in both letters that he had yet to meet the "man" in person: "He is just now in the Countrey, so that I have not yet seen him," 84 "the Gentleman is not at present in Town, tho" he will return in a few days." 85 In the letter to Birch, he adds the following qualification: "I promise myself abundance of Pleasure from his Conversation. I must likewise add, that he has a fine Library, so that we shall have all Advantages for Study.” In annotating the letter to Ramsay, Burton conjecturally identified the man as NoëlAntoine Pluche, "a native of Reims, the greatest literary ornament of that city," and offered a précis of Pluche's intellectual sympathies: "His promotion in the Church was checked by his partiality for Jansenism. He had the rare merit of uniting to a firm belief in the great truths of Christianity a wide and full toleration of the conscientious opinion of others." 86 In annotating the same letter, Greig rejected Burton's identification of the "man" as Pluche: "the Abbé," Greig noted curtly, "had left Reims before Hume went to France." 87

In the light of Greig's note, identifying Hume's contact in Reims became a matter of significant speculation, as it pertained directly to Hume's intellectual connections and reading during the period in France when he drafted A Treatise of Human Nature - a period about which we know "next to nothing." 88 In 1942, Fernand Baldensperger made a case for identifying the contact as Louis-Jean Lévesque de Pouilly

\footnotetext{
${ }^{82}$ Hume, The Letters of David Hume, 1:22-23.

${ }^{83}$ Burton, Life and Correspondence of David Hume, 1:51-56.

${ }^{84}$ Hume, The Letters of David Hume, 1:19.

${ }^{85}$ Hume, The Letters of David Hume, 1:22.

${ }^{86}$ Burton, Life and Correspondence of David Hume, 1:52nl.

${ }^{87}$ Hume, The Letters of David Hume, 1:19n3.

${ }^{88}$ Hume, The Letters of David Hume, 1 :xxii.
} 
(1691-1750), ${ }^{89}$ a member of the Académie des Inscriptions et Belles-Lettres, whose Nouveaux essais de critique sur la fidélité de l'histoire, presented to the Académie in 1724, resembled passages in Hume's "Of Miracles." from Paris to Reims, his place of birth, and resided there in 1734, the year of his only son's birth (March) and Hume's visit (September). Pouilly possessed a home in Reims on the rue de Vesle and, through marriage, a chateau in Arcis-le Ponsart, thirty kilometers west of the city. ${ }^{91}$ He corresponded with Ramsay's acquaintance Henry St. John (1678-1751), Viscount Bolingbroke on philosophical matters in $1720,{ }^{92}$ and his Théorie des sentiments agréables (first published in 1736) ${ }^{93}$ was far closer in sympathy to Hume's Treatise than the natural theology of Pluche's Le spectacle de la nature, or the Christian apologetic of Pluche's Lettre sur la Sainte Ampoule et sur le sacre de nos rois à Reims (1719), which had sought to defend the miraculous story of the baptism of Clovis I (CE 508), according to which the Holy Ampulla of Reims was transported to the hands of Saint Remigius by a dove. ${ }^{94}$ Like Bolingbroke, Pouilly's brother Gérard Lévesque de Champeaux (1694-1778) had

${ }^{89}$ Fernand Baldensperger, "La première relation intellectuelle de David Hume en France: Une conjecture," Modern Language Notes 57, no. 4 (1942): 268-71. For Pouilly, see [Pierre de Saulx], "Éloge historique de M. de Pouilly, lieutenant des habitans, de la ville de Reims," in Louis-Jean Lévesque de Pouilly, Théorie des sentiments agréables (Paris, 1774), 1-76; Jean-Vincent Genet, "Étude sur la vie, l'administration et les travaux littéraires de Louis-Jean Lévesque de Pouilly," Travaux de l'Académie Nationale de Reims 66, no. 3 (1878-79): 1-199, republished as Genet, Une famille rémoise au XVIIIe siècle (Reims, 1881); Henri Jadart, "Jean-Simon Lévesque de Pouilly, lieutenant général au Présidial de Reims, membre de l'Acacémie des Inscriptions et Belles Lettres (1734-1820)," Travaux de l'Académie de Reims 131, no. 1 (1912-13): 349-77, at 375; Herbert Golden, "Louis-Jean Lévesque de Pouilly (1691-1750)" (PhD diss., Harvard University, 1951); Raskolnikoff, Histoire romaine et critique historique, 99-161.

${ }^{90}$ For Pouilly's Nouveaux essais, see George H. Nadel, "Pouilly's Plagiarism," Journal of the Warburg and Courtauld Institutes 30 (1967): 438-44. For the parallels between Hume's "Of Miracles" and Pouilly's Nouveaux essais, see David Wootton, "Hume's 'Of Miracles': Probability and Irreligion," in Studies in the Philosophy of the Scottish Enlightenment, 191-229, at 194n8; Dario Perinetti, "Hume at La Flèche: Skepticism and the French Connection," Journal of the History of Philosophy 56, no. 1 (2018): 45-74, at 63-64.

${ }^{91}$ Genet, "Étude sur la vie," 23, 73nl; Jean-Baptiste-François Géruzez, Description historique et statistique de la ville de Reims, 2 vols. (Reims-Paris-Châlons, 1817), 2:525; P. M. R. Mercier, "Précis statistique et historique de la commune d'Arcy-le-Ponsart, suivi de l'histoire de l'abbaye d'Igny," Travaux de l'Académie Nationale de Reims 54, no. 1 (1872-73): 102-239, at 154-55; Voltaire, Les oeuvres complètes de Voltaire: Correspondence and Related Documents, ed. Theodore Besterman, 2nd ed., 51 vols. (Oxford, 1968-1977), 8:240 (letter D2645).

${ }^{92}$ Henry St. John, Viscount Bolingbroke, "The Substance of Some Letters, Written Originally in French, about the Year 1720, to Mr. de Pouilly," in The Works of the late Right Honourable Henry St. John, Lord Viscount Bolingbroke, 5 vols. (London, 1754), 3:183-254; Henry St. John, Viscount Bolingbroke, The Unpublished Letters of Henry St John, First Viscount Bolingbroke, ed. Adrian Lashmore-Davies, 5 vols. (London, 2013), 5:297-300. For Pouilly's friendship with Bolingbroke, see Alexander Pope, The Correspondence of Alexander Pope, ed. George Sherburn, 5 vols. (Oxford, 1956), 2:221; Golden, "LouisJean Lévesque de Pouilly," 23-32. For Ramsay's acquaintance with Bolingbroke, see G. D. Henderson, Chevalier Ramsay (London, 1952), 134, 146; Joseph Spence, Observations, Anecdotes, and Characters of Books and Men, ed. James M. Osborn, 2 vols. (Oxford, 1966), 1:449.

${ }^{93}$ For Pouilly's Théorie, see Charles Bourdel, "La Théorie des sentiments agréables de Lévesque de Pouilly (1691-1750)," Travaux de l'Académie Nationale de Reims 109, no. 1 (1900-01): 279-325; Golden, "Louis-Jean Lévesque de Pouilly," 160-384; Corrado Rosso, Moralisti del bonheur (Turin, 1954), 1948; Robert Mauzi, Lidée du bonbeur dans la littérature et la pensée françaises an XVIIIe siècle (Paris, 1994), 240-49.

${ }_{94}$ Noël-Antoine Pluche, Lettre sur la Sainte Ampoule et sur le sacre de nos rois à Reims (Paris, 1775), $32-45$. 
frequented the Club de l'Entresol-the intellectual salon coordinated by PierreJoseph Alary (1689-1770) in Paris-between ca. 1724 and 1726, where it is conceivable that he formed an acquaintance with Ramsay, who was a fellow member. ${ }^{95}$

In response to Baldensperger's claim, Mossner's Life of David Hume (1954) settled on Pouilly as the individual "who best fits Hume's rather thin description," and neglected to mention Pluche or his candidacy in any form. ${ }^{96}$ It was clear that Hume was interested in Pouilly's Théorie-a work that he would later own himself, and purchase for the Advocates Library in Edinburgh-in a way that he would never demonstrate for any work in Pluche's oeuvre. ${ }^{97}$ Letter 1, however, exploded Mossner's surmise. In the second edition of his Life of David Hume (1980), Mossner quoted from Letter 1 at length and stated categorically that Hume's contact in Reims was "the Abbé Noel-Antoine Pluche." Baldensperger's "conjecture," he added, was "proved incorrect" by Morrisroe's discovery. 98 The resultant consensus has echoed Mossner's judgment. John Robertson's entry for Hume in the Oxford Dictionary of National Biography notes that Hume received "several introductions" from Ramsay, "notably to the Abbé Pluche." 99 In their work on Hume's intellectual development, Annemarie Butler, Roger L. Emerson, Ian Simpson Ross, Margaret Schabas, and several others have reiterated this particular claim:

- "While in Rheims, Hume enjoyed access to the library of Abbé Noel-Antoine Pluche. There he read and re-read various classics and contemporary works in French and English, including Locke's Essay and Berkeley's Principles" (Butler). ${ }^{100}$

${ }^{95}$ For Bolingbroke, Champeaux, and Ramsay at the Club de l'Entresol, see Henry St. John, Viscount Bolingbroke, Lettres historiques, politiques, philosophiques et particulières de Henri Saint-John, lord vicomte Bolingbroke, depuis 1710 jusqu'en 1736, ed. Philippe-Henri de Grimoard, 3 vols. (Paris, 1808), 3:193, 206-7; René-Louis de Voyer, Marquis d'Argenson, Journal et mémoires du marquis d'Argenson, ed. Edmé-Jacques-Benoît Rathery, 9 vols. (Paris, 1859-1867), 1:9lnl, 93-94; Nick Childs, A Political Academy in Paris, 1724-1731: The Entresol and its Members (Oxford, 2000), 6, 10, 72-73, 87-91.

${ }^{96}$ Ernest Campbell Mossner, The Life of David Hume (London, 1954), 97.

${ }^{97}$ For Hume's copy of Pouilly's work (William Andrews Clark Memorial Library, University of California, Los Angeles), see Norton and Norton, The David Hume Library, 18, 46. For his purchase of a copy for the library of the Faculty of Advocates, see John Spink, "Levesque de Pouilly et David Hume: 'Bienveillance' et 'justice', 'sentiments agréables' et 'calm passions," Revue de Littérature Comparée 56, no. 2 (1982): $157-75$, at 158 n5, citing NLS, F.R. 118 (23 January 1753), a portion of the manuscript that is now missing. For an image of one page from this lost portion of the manuscript, see Brian Hillyard, "The Keepership of David Hume," in For the Encouragement of Learning: Scotland's National Library 1689-1989, ed. Patrick Cadell and Ann Matheson (Edinburgh, 1989), 103-9, unnumbered plate. Paul H. Meyer, "Hume in Eighteenth-Century France" (PhD diss., Columbia University, 1954), 9, transcribes an entry in an undated Charavay auction catalogue, advertising a letter from Claude-Adrien Helvétius (1715-1771) to Pouilly of ca. 1743, which records Helvétius's judgment that Pouilly's Théorie resembles the "Recherches sur le principes de la morale, par Hume"; the located (fragmentary) manuscript of the letter reveals that it was addressed to Pouilly's son Jean-Simon (1734-1820) in ca. 1765 and refers, in fact, to the latter's Théorie de l'imagination (first published in 1803); see Claude Adrien Helvétius, Correspondance générale d'Helvétius, ed. David Smith et al., 5 vols. (Toronto, 1981-2004), 3:151-55. The only evidence of Hume's engagement with the Jansenist theology propounded by Pluche is his acid criticism of the convulsionnaires of Saint-Médard in Hume, An Enquiry Concerning Human Understanding, 93.

${ }_{98}$ Mossner, Life of David Hume (1980), 97.

99 Robertson, "Hume, David (1711-1776)," 742.

${ }^{100}$ Butler, "Hume's Early Biography and A Treatise of Human Nature," 4. 
- "Indeed, while he was in France he had met a number of important intellectuals and had been given access to the library of the Abbé Pluche" (Emerson). ${ }^{101}$

- "[T]he immediate attraction of Reims for Hume was that he had an introduction to its chief man of letters: the abbé Noël-Antoine Pluche" (Ross). ${ }^{102}$

- "One leading savant at Reims, Noël-Antoine Pluche, provided Hume with access to his library" (Schabas). ${ }^{103}$

The trouble is that Pluche did not reside in Reims in 1734. ${ }^{104}$ Although he was born there in 1688 and had served a professor in its Collège des Bons Enfants from 1710, ${ }^{105}$ Pluche had departed Reims for Laon in August 1717, where he acted as the principal of its Collège Municipal and found refuge from François de Mailly (1658-1721), the archbishop of Reims, who had attempted to purge Jansenists from the ranks of the city's clergy after the promulgation of the papal bull Unigenitus in September 1713. In Laon, Pluche received protection from Louis Annet de Clermont (1662-1721), the bishop of Laon, but Clermont's failing health, and the bull Pastoralis officii (August 1718), threatening excommunication for clerics who had refused to accept Unigenitus, forced Pluche's departure from the diocese in 1722. ${ }^{106}$ According to the most significant authority on Pluche's life, the Éloge historique de Monsieur l'Abbé Pluche (1764) by Pluche's publisher Robert Estienne (17231794), Pluche left Laon for Rouen, fearful of a lettre de cachet for his intransigent Jansenism. In Rouen, Pluche served as a tutor to the children of Jean-Prosper Goujon de Gasville (1684-1755), the intendant of Rouen, and to the son of William Stafford-Howard (ca. 1690-1734), second Earl of Stafford. ${ }^{107}$ His exact movements in the later 1720s are difficult to reconstruct, but he appears to have relocated to Paris before 1732, where he devoted himself to the composition of Le spectacle de la nature. From the evidence of Estienne, and a small number of surviving letters, sent from Paris, ${ }^{108}$ Pluche resided in the city for the remainder of his life, writing the nine volumes of his chef d'oewvre before retiring in 1749 to Ivry-sur-

${ }^{101}$ Emerson, Essays on David Hume, 85.

${ }^{102}$ Ross, "The Emergence of David Hume as a Political Economist," 40.

103 Schabas, Natural Origins of Economics, 68.

${ }^{104}$ For the fullest study of Pluche's life, see Caroline V. Doane, "Un succès littéraire du XVIIIe siècle: $L e$ spectacle de la nature de l'abbé Pluche” (thèse d'université, University of Paris, 1957), 1-78.

${ }_{105}$ Eugène Cauly, Histoire du Collège des Bons-Enfants de l'Université de Reims depuis son origine jusqu'à ses récentes transformations (Reims, 1885), 474, 480-82.

106 Charles Taiée, "L'enseignement secondaire à Laon," Bulletin de la Société Académique de Laon, no. 23 (1877-78): 77-295, at 223, 224nl; Doane, "Un succès littéraire," 22nl.

${ }^{107}$ Robert Estienne, "Éloge historique de Monsieur l'Abbé Pluche," in Noël-Antoine Pluche, Concorde de la géographie des différens ages (Paris, 1764), v-xxix, at xiii-xiv.

${ }^{108}$ For these letters, see MS 1998/240 (20 February 1737), Muséum National d'Histoire Naturelle, Paris; "Copie littérale de deux traités passés entre l'Abbé Pluche, et la Veuve Etienne, libraire à Paris," Revue Mensuelle de la Littérature, des Sciences et des Arts, no. 1 (1853): 12-15 (1 May 1739), addressed to the publisher of Le spectacle de la nature; MS fr. 12765, fols. 62r-3v (9 November 1743), Bibliothèque Nationale de France, addressed to Jean-Baptiste Baussonnet (1700-75) and Charles Taillandier (1706-86) in Reims, requesting their communication of samples of writing from early French-language monuments in the city, in order to compile a "paléographie" of the language for students; Autographes, Première Collection de la Ville, 1, 139 (10 October 1743), Bibliothèque Carnegie, Reims, addressed to an unidentified bishop, announcing the completion of Le spectacle de la nature; Legs Pol Gosset, Autographes rémois and champenois, 2827/1 (5 April 1741), Bibliothèque Carnegie, Reims, addressed to a "M. Lecot"; MS fr. 9103/1, items 8, 13, 64, 71 (28 July 1741, 23 June 1742, 15 April 1747, 16 September 1747), and 
Seine and Varenne-Saint-Maur (Saint-Maur-des-Fossés), on the outskirts of the city. ${ }^{109}$ Within two years of his death, an auction of Pluche's modest library was held in Paris. A published catalogue of the library listed the 1729 Amsterdam edition of Pierre Coste's French translation of Locke's Essay, but not a single work by Locke in English or by Berkeley, "in original state" or otherwise. ${ }^{110}$ A probate inventory of Pluche's belongings recorded his profession as "Prêtre du diocèse de Reims," 111 and a clause in his will stipulated that his belongings would escheat to the city of Reims in the event of the death of his principal beneficiaries, ${ }^{112}$ but Pluche's connection to his place of birth was evidently limited after his exilic departure in 1717.

In 1992, Mouza Raskolnikoff noted in her remarkable Histoire romaine et critique historique dans l'Europe des Lumières that Pluche's recorded movements after 1717 presented a discrepancy for the apparent narrative in Morrisroe's letter. Raskolnikoff resolved the discrepancy by arguing that Hume, in Letter 1, had not claimed to have met Pluche in person, but-more precisely-to have had access to Pluche's library. ${ }^{113}$ This theory is an ingenious response to the contrarieties presented by Letter 1 , but it requires us to assume that Pluche resided in Reims in 1734, and temporarily maintained a library in the city, when no evidence can be found to support either assumption. Pluche's will does not refer to any properties in the city of Reims. Moreover, his library catalogue hardly reflects the "latest" of "Learning \& Philosophy from London and Paris," ca. 1734, unless one allows for significant deaccessions between the year of Hume's visit and the posthumous cataloguing of Pluche's library in 1763. Although Pluche owned several publications from 1732 to 1734, his holdings from this period were principally works on religious devotion or ecclesiology. Works of philosophy were limited to Edmond Pourchot's Institutiones philosophicae (Paris, 1733) and the third Earl of Shaftesbury's Characteristicks of Men, Manners, Opinions, Times (London, 1733), John Theophilus Desaguliers's A Course of Experimental Philosophy (London, 1734), Pierre Polinière's Expériences de physique (Paris, 1734), and unspecified numbers of Histoire et Mémoires de l'Académie Royale des Sci-

MS fr. 9103/2, items 45, 58 (12 April 1750, 18 August 1750), Bibliothèque de Genève, a series of letters addressed to Gabriel Seigneux de Correvon (1695-1776).

${ }^{109}$ Estienne, "Éloge historique de Monsieur l'Abbé Pluche," xix.

${ }^{110}$ Catalogue des livres de feu M. l'Abbé Pluche; dont la vente se fera en detail, au plus offrant et dernier enchérisseur le lundi 24 janvier 1763 et jours suivans, en une salle du Couvent des Grands Augustins (Paris, 1763), inventoried in Daniel Roche, "Les enseignements des bibliothèques privées (1750-1780)," Revue d'Histoire Littéraire de la France 17, no. 3 (1910): 449-96, at 493 and transcribed in Benoit De Baere, Trois introductions à l'Abbé Pluche: Sa vie, son monde, ses livres (Geneva, 2001), 136-93.

${ }^{111}$ MC/ET/LXXVI/382, Archives Nationales, Paris, "Inventaire après décès de Antoine Pluche, à la requête de Jean François Roland de Challerange, chevalier, conseiller du Roi en sa cour de Parlement, demeurant à Paris rue des Massons et paroisse Saint-Séverin, au nom et comme exécuteur du testament et ordonnance de dernière volonté de défunt Antoine Pluche, prêtre du diocèse de Reims, par lui fait en date du 6 février 1758.”

112 Châtelet de Paris, Y//68, fol. 218r-v, Archives Nationales, Paris; MS 1299, fol. 32r, Bibliothèque Carnegie, Reims; the latter is inventoried in Henri Loriquet, ed., Catalogue général des manuscrits des bibliothèques publiques-Reims, XXXIX, vol. 2 (Paris, 1904), pt. 1, 459 and abstracted in Charles Loriquet, "Rapport sur le Concours d'Histoire Littéraire," Travaux de l'Académie Impériale de Reims 22, no. 2 (1854-55): 202-13, at $2 \ln 1$.

113 Raskolnikoff, Histoire romaine et critique historique, 146. 
ences (Paris, 1666-1750) and Philosophical Transactions of the Royal Society (London, 1716-1734). ${ }^{114}$

A final-somewhat unusual-difficulty for the content of Letter 1 is presented by Hume's reference to "the Abbé Noel-Antoine Pluche." Despite its prominence in studies of Pluche, "Noël" was not Pluche's forename at birth, either on its own or in combination with "Antoine." According to Estienne, during Pluche's flight from a lettre de cachet in 1722, he adopted the pseudonym "l'abbé Noël" to evade persecution. ${ }^{115}$ In the period of his residence in Rouen, Pluche reportedly used the pseudonym. Yet Pluche's will and the formal record of his burial continued to give his name as "Antoine Pluche," 116 and the engraving of Pluche that Estienne prefixed to his Éloge historique de Monsieur l'Abbé Pluche of 1764 would use the same-merely binominal-form. Pluche's works and translations were either published anonymously in his lifetime or credited to "M. Pluche."117 His extant letters, when signed, uniformly adopt "Pluche" after the valediction. ${ }^{118}$ Early biographical dictionaries referred to Pluche only as "Pluche, Abbé Antoine," 119 with the significant exception of Joseph de La Porte's La France littéraire (1756), a biographical register of living gens de lettres, which used "Pluche, Noël-Antoine" in its entry for his writings. ${ }^{120}$

De La Porte's choice has subsequently shaped the bio-bibliographical literature on Pluche, ${ }^{121}$ but in the judgment of one of Pluche's early rémois biographers, its use is erroneous: Pluche's name was "Antoine," tout court. ${ }^{122}$ On the basis of this objection,

${ }^{114}$ De Baere, Trois introductions, 135-93, items 22, 29, 37, 42, 59, 95, 99, 173, 493, 501 (devotional works); items 157, 186, 268, 270, 560, 563 (works of philosophy).

115 Estienne, "Éloge historique de Monsieur l'Abbé Pluche," xiii.

116 Doane, "Un succès littéraire," 6nl, 70.

${ }^{117}$ For a bibliography of Pluche's publications, see Doane, "Un succès littéraire," 498-553; Alexandre Cioranescu, Bibliographie de la littérature française du dix-huitième siècle, 3 vols. (Paris, 1969), 2:1405-6.

118 For Pluche's extant letters, see note 108 above and Doane, "Un succès littéraire," 8, 20.

119 Louis-Mayeul Chaudon, Nouveau dictionnaire historique-portatif, 4 vols. (Amsterdam, 1766), 3:58990; Jean-Bernard Restout, ed., Galerie françoise, ou portraits des hommes et des femmes célèbres qui ont paru en France, 2 vols. (Paris, 1771), 2:viii; Antoine Sabatier de Castres, Les trois siècles de notre littérature, 3 vols. (Amsterdam, 1772), 3:85; Aimé-Henri Paulian, Dictionnaire de physique, 3 vols. (Nîmes, 1773), 3:221; Jacques Lelong and Charles-Marie Fevret de Fontette, Bibliothèque historique de la France, contenant le catalogue des ouvrages, imprimés et manuscrits, qui traitent de l'histoire de ce royaume, 5 vols. (Paris, 1768-1778), 4:250; [Pierre Mouchon], ed., Table analytique et raisonnée du Dictionnaire des sciences, arts et métiers et dans son supplement, 2 vols. (Paris, 1780), 2:467; A New and General Biographical Dictionary, 12 vols. (London, 1784), 1:xxvi; 10:392; Samuel Baur, Neues historisch-biographisch-literarisches Handwörterbuch, 7 vols. (Ulm, 1807-1816), 4:col. 426.

${ }^{120}$ [Joseph de La Porte], La France litteraire, contenant les noms et les ouvrages des gens de lettres (Paris, 1756), 176.

${ }^{121}$ For subsequent uses of "Noël-Antoine," see Johann Heinrich Samuel Formey, La France littéraire, on Dictionnaire des auteurs françois vivans (Berlin, 1757), 263; Nicolas Lenglet Dufresnoy, Tablettes chronologiques de l'histoire universelle: Sacrée et profane, ecclésiastique et civile, 2 vols. (Paris, 1778), 2:840; AntoineAlexandre Barbier, Dictionnaire des ouvrages anonymes et pseudonymes, 4 vols. (Paris, 1806-1809), 1:358; Louis-Gabriel Michaud, Biographie universelle, ancienne et moderne, 85 vols. (Paris, 1811-1862), 35:89; Joseph-Marie Quérard, La France littéraire ou dictionnaire bibliographique, 12 vols. (Paris, 1827-1864), 7:217-18; Jean-Chrétien-Ferdinand Hoefer, ed., Nouvelle biographie générale, 46 vols. (Paris, 18521862), 40:cols. 498-99.

${ }^{122}$ For a complaint about the use of "Noël" as a forename for Pluche, see the anonymous "Labrégé de la vie de M. l'abbé Pluche," in Noël-Antoine Pluche, Mécanique des Langues et l'Art de les Enseigner (Brest, 1811), iv-xiv, at ivnl. 
Hume's reference to "Noel-Antoine Pluche" would reveal letter 1 to be the spurious product of a misunderstanding, inaugurated by de La Porte and perpetuated by scholars since 1756: Pluche could not possibly have introduced himself to Hume as "Noël-Antoine." However, a significant piece of evidence definitively upsets this objection, in a way that incidentally establishes Pluche's place of residence in 1734. The only extant evidence of Pluche's use of "Noël-Antoine" as a forename is his attestation to the testament (14 December 1733 and 2 January 1734), ${ }^{123}$ burial record (31 December 1733), ${ }^{124}$ and inventaire après décès (11-13 March 1734) of the painter Robert de Séry (1686-1733) né Paul Ponce Antoine Robert of Sery-enPorcien. The inventaire, signed "Noel Ant. Pluche," refers to Pluche as "prestre du dioceze de Reims, demeurant à Paris, rue des Carmes, pa[roi]sse $S^{t}$ Benoist,"125 the same address Pluche would adopt in correspondence in $1743 . .^{126}$ It is possible that Pluche maintained two addresses in 1734, one in Paris on the rue des Carmes, and another in Reims, but one would have to ask why he declined to acknowledge a residence in Reims in these attestations or any other extant document. The simple truth, as Greig noted in 1932, is that Pluche did not live in Reims during the period of Hume's visit, or after 1717.

\section{AD FONTES}

In 1984, M. R. Ayers and Harry M. Bracken urged caution against the use of Letter 1. Ayers stated that "no weight" could be placed on the letter, "as long as it is unavailable to resolve any doubts about its authenticity."127 Bracken wondered whether Morrisroe "saw the original" of the letter and how he had established "Hume['s]

\footnotetext{
${ }^{123}$ MC/ET/XXIX/416, Archives Nationales, Paris, printed in Henri Bourin, Paul-Ponce-Antoine Robert (de Sery), peintre du Cardinal de Rohan (1686-1733) (Paris, 1907), 13-14. The testament appoints Pluche as Sery's executor; Pluche (signing himself "Noel Ant. Pluche") accepted the role six days after Sery's death on 29 December 1733.

${ }^{124}$ Henri Herluison, Actes d'état-civil d'artistes français: Peintres, graveurs, architectes: Extraits des registres de l'Hôtel-de-Ville de Paris, détruits dans l'incendie du 24 mai 1871 (Paris, 1873), 386, drawn from the registers of the church of St. Jean en Grève, destroyed by a fire in 1871; the record was reportedly signed "Noël-Ant. Pluche."

${ }^{125}$ MC/ET/XXIX/417, Archives Nationales, Paris, printed in Bourin, Paul-Ponce-Antoine Robert (de Sery), 46-62.

${ }^{126}$ Autographes, Première Collection de la Ville, 1, 139 (10 October 1743), Bibliothèque Carnegie, Reims, cited above, note 108: "Mon adresse est Pluche, rue des Carmes de la place Maubert, à Paris." For additional evidence of Pluche's association with this address, see [Noël-Antoine Pluche], Le spectacle de la nature, 12 vols. (Paris, 1755), 6:137n.*-a passage absent from the 1746 and 1747 Paris editions of the same volume. The note refers to a "coffret" or box constructed by "M. Chompré, rue des Carmes de la Place Maubert," presumably the educationalist Pierre Chompré (1698-1760), whose Selecta Latini sermonis exemplaria (Paris, 1749-1753) is cited approvingly in Pluche's La mécanique des langues (Paris, 1751), 104n(a), and whose acquaintance with Pluche is discussed in [Élie Catherine Fréron], ed., L'année littéraire, vol. 2 (Amsterdam, 1757), 294, and Bibliothèque Carnegie, Reims, Legs Pol Gosset, Autographes rémois and champenois, 2827/1, a receipt of sale from Pluche to Chompré of 24 April 1758, "de biens acquis d'Antoine Chaumont de Cuier."

${ }^{127}$ M. R. Ayers, "Berkeley and Hume: A Question of Influence," in Philosophy in History: Essays on the History of Philosophy, ed. Richard Rorty, J. B. Schneewind, and Quentin Skinner (Cambridge, 1984), 30327 , at 325 .
} 
authorship."128 In 2015, James Harris's Hume: An Intellectual Biography used an endnote to describe Letter 1 as a "hoax," adding that "scope for scepticism" should exist about Letter 2. Harris maintained that his doubt about Letter 1 was the "consensus among Hume scholars." 129 Yet this consensus, pace Harris, is nowhere to be found in print, aside from Ayers's and Bracken's tentative reservations. Indeed, the forgeries published by Morrisroe are so tightly interwoven with scholarship on Hume's life that Harris's biography commences its discussion of Reims with the claim that Hume's contact in the city was either Pouilly or "the Abbé NoelAntoine Pluche." 130 Where a consensus has emerged about Morrisroe's discoveries, it has been noted in private. In a draft introduction to their critical edition of Hume's Treatise, circulated among a small group of scholars in November 2000, David Fate Norton and Mary Norton expressed doubt about Mossner's reliance on Letter 1. "Regrettably" they noted, "the location of the manuscript of this letter is not available for inspection, while the letter as published raises doubt about its authenticity." One reviewer of the Nortons' draft underlined this phrase and used a marginal annotation to refer to Morrisroe's later activities as an entrepreneur. ${ }^{131}$ Between 1979 and 1983, Morrisroe was subpoenaed by Congress and investigated by a federal grand jury when he was accused of "complex" Medicare fraud. ${ }^{132}$ The allegations against Morrisroe included the claim that he had "fabricated" patient records. ${ }^{133}$

These doubts and allegations were never publicized by the Nortons; their discussion of Letter 1 was excised from the published text of their edition, and their subsequent publications do not discuss Morrisroe or Letter 1 in any form. Media coverage of the allegations against Morrisroe did not refer to his career as a scholar of Hume or to any of his academic activities. The separation of these two personae, the academic and the alleged perpetrator of a crime, may explain why Morrisroe's work has continued to enjoy the endorsement of scholars-including this author, whose Further Letters of David Hume (2014) recorded the presence of Letter 1 and Letter 2 in its census of Hume's "known" manuscripts. Yet whether Morrisroe's alleged activities later in life should have any bearing on the integrity of his scholarship is not in question. We must not rule out the deceptions of a third party: Ronald H. Miller, Patrick J. Kelly, or a latter-day Alexander "Antique" Smith. It is clear that Letter 1 contains a phrase-"the Principles of Human

${ }^{128}$ Harry M. Bracken, "Hume on the 'Distinction of Reason,” Hume Studies 10, no. 2 (1984): 90-109, at 90 .

129 James Harris, Hume: An Intellectual Biography (Cambridge, 2015), 490n3.

${ }^{130}$ Harris, Hume, 78.

${ }^{131}$ David Fate Norton Papers, Box F, “INTROHUM.010: 28 November 2000," marginal note by Roger L. Emerson, p. 7, McGill University Library, Montreal.

${ }_{132}$ William Gaines, "U.S. Probing Cheating on Medicare," Chicago Tribune, 28 January 1979, 12.

${ }^{133}$ Home Health Care Frand and Abuse: Hearings Before the Permanent Subcommittee on Investigations of the Committee on Governmental Affairs (Washington, DC, 1981), 46-47. For additional coverage of the allegations, see Howie Kurtz, "Home Care Ripoff: There's a Hole in the Program," New Republic, 6 June 1981, 11-14; Arthur Siddon, "Congress Told of \$1 Million Medicare Fraud Here," Chicago Tribune, 14 May 1981, 12; Arthur Siddon, "Medicare Fraud Laws Are Urged," Chicago Tribune, 12 October 1981, 1; Report No. 97-210: Report of the Committee on Governmental Affairs United States Senate made by its Permanent Subcommittee on Investigations (Washington, DC, 1981), 7-27; James O'Shea, "Offshore Banks Are Used to Cheat IRS of Fortune," Chicago Tribune, 24 January 1983, 3; Richard H. Blum, Offshore Haven Banks, Trusts, and Companies: The Business of Crime in the Euromarket (New York, 1984), 115. 
Knowledge by Dr Berkeley" (L) — that must have derived from the forger's acquaintance with recent scholarship on Hume, ca. 1964. The phrase is used by Hume uniquely in the letter to Ramsay of 1737 that Kozanecki published in 1963 and Popkin reprinted in 1964 for an anglophone readership. ${ }^{134}$ It is quite possible that Morrisroe was the butt of a sophisticated ruse, conceived between 1963 and 1972 and facilitated by a man (Ronald H. Miller) who died during its execution. An alternative conclusion is that Morrisroe forged the letters himself, quilting together relevant phrases from authentic letters and passing off the confection as a "discovery." But this is not a contention that the present article can endorse, given the limitations of the available evidence.

The implications of the story told so far may feel familiar. The misplaced good faith of a scholarly community, the authority conveyed by the appurtenances of "good" scholarship, the respectability afforded by the filtrations of peer review: all appear in other recent hoaxes, alongside routine enjoinders for safeguards against further abuse. ${ }^{135}$ The exposure of the forgeries published by Morrisroe can only renew these calls for rigor in the assessment of sources, but it can also allow us to revise our suppositions about Hume's early life and later historical scholarship. We can now revisit the debate over whether Hume ever read the works of George Berkeley. ${ }^{136}$ We can reopen the question of Hume's rémois acquaintance and give new credence to Baldensperger's conjecture. ${ }^{137}$ We can reconsider why Hume might have abandoned his plans to write an ecclesiastical history. ${ }^{138}$ And we can continue to rewrite Hume's biography, in the light of an ever-increasing body of new-authentic-sources.

The route to these implications may seem tortuous, the ardor applied in exposing the forgeries disproportionate to the questions at stake. It could be argued, for example, that Hume's supposed acquaintance with Pluche or his interest in writing an ecclesiastical history in 1765 have had a negligible effect on the interpretation of his thought. Correcting the historical record would warrant only an endnote or a parenthetical expression of doubt, alerting others to problems in "phraseology or other considerations," as Ayers put it, in his brisk discussion of Letter 1 in 1984. In the case of the forgeries published by Morrisroe, this mode of correction has evidently failed; a conspicuous exposé is overdue. Yet the exposure of a forgery must always amount to more than the mere "righting" of an imposture. It is a reiteration

${ }^{134}$ Kozanecki, "Dawida Hume,” 133-34; Popkin, “So, Hume Did Read Berkeley, 774-75.

${ }^{135}$ For a recent sample of hoaxes, see Eric Naiman, "Their Mutual Friend," Times Literary Supplement, 12 April 2013, 16-21; Leo Depuydt, "The Alleged Gospel of Jesus's Wife: Assessment and Evaluation of Authenticity," Harvard Theological Review 107, no. 2 (2014): 172-89; Nick Wilding, "Forging the Moon," Proceedings of the American Philosophical Society 160, no. 1 (2016): 37-72.

${ }^{136}$ For a provocative examination of this question, see David Raynor, "Hume and Berkeley's Three Dialogues," in Stewart, Studies in the Philosophy of the Scottish Enlightenment, 231-51.

${ }^{137}$ For a significant use of Baldensperger's conjecture, see John Spink, "Levesque de Pouilly et David Hume," 157-75. For Adam Smith's considerable interest in Pouilly's Théorie, see [Adam Smith], "A Letter to the Authors of the Edinburgh Review," in Adam Smith, Essays on Philosophical Subjects and Miscellaneous Pieces, ed. W. P. D. Wightman and J. C. Bryce (Oxford, 1980), 242-54, at 250; D. D. Raphael and A. L. Macfie, introduction to Adam Smith, The Theory of Moral Sentiments, ed. D. D. Raphael and A. L. Macfie (Oxford, 1976), 1-52, at 14-15.

${ }^{138}$ For a constructive suggestion, see Roger L. Emerson, "Hume and Ecclesiastical History: Aims and Contexts," in David Hume: Historical Thinker, Historical Writer, ed. Mark G. Spencer (University Park, 2013), 13-36. 
of the importance of tools that are coeval with scholarship itself: text-critical analysis, historical bibliography, provenance research. The history of scholarship has long recognized the importance of these pursuits to the emergence of the humanities. ${ }^{139}$ The ars critica or proto-philological forms of textual criticism were indispensable tools in the formation of modern scholarly research-and the recent neglect of its methods, in the waning vogue for critical editions, is the cause of warrantable anxiety among its surviving practitioners. ${ }^{140}$ Inventories of "secondary sources" on Hume have long served students of his life and writings. ${ }^{141}$ Yet considerable lacunae remain: we still lack a critical edition of Hume's correspondence, a comprehensive census of his manuscripts, and a systematic bibliography of his publications. Although forgers with sufficient expertise will find a means to exploit these absences, blithe confidence in a critical or "standard" text is no less hazardous. It is clear that the faith placed by scholars in the authority of Mossner's Life is a principal cause for the incessant citation of the forgeries' extraordinary claims. If one possible justification of a forgery is that it may serve as a fillip for the revival of a discipline's best practices, an ironic justification - in this case, at least-is that it may remind us of Hume's banal maxim in "Of Miracles: "a wise man ... proportions his belief to the evidence."142

${ }^{139}$ For classic statements, see Sebastiano Timpanaro, The Genesis of Lachmann's Method, ed. and trans. Glenn W. Most (Chicago, 2005); Anthony Grafton, Forgers and Critics: Creativity and Duplicity in Western Scholarship, new ed. (Princeton, 2019); Grafton, Defenders of the Text: The Traditions of Scholarship in an Age of Science (Cambridge, MA, 1991); Joseph M. Levine, Humanism and History: Origins of Modern English Historiography (Ithaca, 1987); C. R. Ligota and J. L. Quantin, introduction to History of Scholarship: A Selection of Papers from the Seminar on the History of Scholarship Held Annually at the Warburg Institute, ed. Ligota and Quantin (Oxford, 2006), 1-38.

${ }^{140}$ For an ambivalent prospectus, see Philippe Régnier, "Toward a New Political Economy of Critical Editions," in Digital Critical Editions, ed. Philippe Régnier, Daniel Apollon, and Claire Bélisle (Urbana, 2014), 266-96.

${ }^{141}$ For these tools, see T. E. Jessop, A Bibliography of David Hume and of Scottish Philosophy from Francis Hutcheson to Lord Balfour (London, 1938); Stanley Tweyman, ed., Secondary Sources on the Philosophy of David Hume (Ann Arbor, 2006).

${ }^{142}$ Hume, Enquiry Concerning Human Understanding, 84. 